Authors: C Himonga, M Taylor and A Pope

\title{
REFLECTIONS ON JUDICIAL VIEWS OF UBUNTU
}

$$
2013 \text { VOLUME } 16 \text { No } 5
$$




\section{REFLECTIONS ON JUDICIAL VIEWS OF UBUNTU}

\section{Himonga*, M Taylor** and A Pope ${ }^{* * *}$}

\section{Introduction}

Defenders of ubuntu as an emerging value in South African law often emphasise its power as a transformative tool to engender a new distinctively African flavour to South Africa's maturing - but still relatively young - democratic legal culture. For Keep and Midgley, ${ }_{1}^{1}$ it is vital that South Africa's legal culture transforms so as to express also the values that originated in African societies, because there is a "real need" in South Africa to legitimate the legal system. On this view, South Africa's legal system and culture are legitimate only if they reflect the demographic and cultural diversity of the country. Keep and Midgley believe that an ideal South African legal culture is one that is cohesive and plural. ${ }^{2}$ Ubuntu is a distinctively African value and, according to Keep and Midgley, it inherently embodies deep notions of inclusivity, making it an "ideal overarching vehicle for expressing shared values" and rendering it very well suited to spearheading the development of a genuinely plural legal culture. ${ }^{3}$

South Africa's interim Constitution included an historic post-amble entitled "National Unity and Reconciliation", which declared: ${ }^{4}$

Chuma Himonga. LLB (U Zambia), LLM PhD (London). Professor of Law in the Department of Private Law; South African National Research Foundation Chair in Customary Law, University of Cape Town. Email: chuma.himonga@uct.ac.za.

** Max Taylor. BA, LLB (Hons), UNSW; BA (Hons), ANU. Research Assistant, University of Cape Town. Email: maxtaylorsyd@gmail.com.

*** Anne Pope. Dip Lib (Stell); BA LLB (Rhodes). PG Dip International Research Ethics (Cape Town); Associate Professor in the Department of Private Law, University of Cape Town. Email: anne.pope@uct.ac.za.We are grateful for the assistance given by Nkanyiso Sibanda; Research Coordinator, South African National Research Foundation Chair in Customary Law, University of Cape Town.

Keep and Midgley "Emerging Role of Ubuntu-botho" 48. Keep and Midgley "Emerging Role of Ubuntu-botho" 30. Keep and Midgley "Emerging Role of Ubuntu-botho" 48. Constitution of the Republic of South Africa Act 200 of 1993. 
The adoption of this Constitution lays the secure foundation for the people of South Africa to transcend the divisions and strife of the past, which generated gross violations of human rights, the transgression of humanitarian principles in violent conflicts and a legacy of hatred, fear, guilt and revenge.

These can now be addressed on the basis that there is a need for understanding but not for vengeance, a need for reparation but not for retaliation, a need for ubuntu but not for victimisation.

This provision was historic at least partly because, for the first time in South Africa's modern history, a traditional African concept - ubuntu - was incorporated in the state's official law. South Africa's 1996 Constitution made no express mention of ubuntu but did recognise customary law "subject to the Constitution", ${ }^{5}$ requiring courts to apply customary law "when that law is applicable, subject to the Constitution and any legislation that specifically deals with customary law". ${ }^{6}$

While it is obvious that ubuntu and customary law are not synonymous, it ought to be equally obvious that, as a fundamental value that informs the regulation of African interpersonal relations and dispute resolution, ubuntu is inherent to customary law.

The recognition of customary law and ubuntu is closely connected with the Constitution's "transformative" nature. It is often said that a distinctive feature of South Africa's Constitution is that it is inherently forward-looking; ie it aims to empower the state to transform South African society over time. Langa DP (as he then was), in Investigating Directorate: Serious Economic Offences v Hyundai Motor Distributors, ${ }^{7}$ stated that a "spirit of transition and transformation characterises the constitutional enterprise as a whole".

Judges are therefore duty-bound to interpret the Constitution in a way that facilitates this transformation. Academic literature refers to this important aspect of South Africa's post-apartheid legal culture as "transformative constitutionalism". The

Constitution of the Republic of South Africa, 1996.

Section 211(3) of the Constitution of the Republic of South Africa, 1996.

Investigating Directorate: Serious Economic Offences v Hyundai Motor Distributors (Pty) Ltd: In re Hyundai Motor Distributors (Pty) Ltd v Smit 20011 SA 545 (CC). 
origin of this phrase is sometimes attributed to Karl Klare. ${ }^{8}$ He described this futureorientated phenomenon as: ${ }^{9}$

a long-term project of constitutional enactment, interpretation, and enforcement committed...to transforming a country's political and social institutions and power relationships in a democratic, participatory and egalitarian direction.

The recognition of customary law is a vital aspect of transformative constitutionalism.

In Mayelane $v$ Ngwenyama ${ }^{10}$ the Constitutional Court recently considered what recognising customary law "as one of the primary sources of law under the Constitution" entails. It held that this involves acknowledging inter alia that: ${ }^{11}$

... the inherent flexibility of customary law provides room for consensus-seeking and the prevention and resolution, in family and clan meetings, of disputes and disagreements; and ... [that] these aspects provide a setting which contributes to the unity of family structures and the fostering of co-operation, a sense of responsibility and belonging in its members, as well as the nurturing of healthy communitarian traditions like ubuntu.

As will be seen, the judicial application of ubuntu and the implementation of restorative justice measures frequently go hand-in-hand. The interim Constitution's contrasting of ubuntu with "victimisation" would therefore prove to have been apt.

Keep and Midgley emphasise that the pluralist legal culture they envision is achievable partly because of considerable overlap between the values embodied by so-called Western models of human rights and those embraced by the concept of ubuntu. A genuinely pluralist South African legal culture, they say, demands a synthesis or harmonisation of Western and African values. ${ }^{12}$ Keep and Midgley endorse what one might call a "teleological" approach to values - focusing on what a

Klare 1998 SAJHR 146.

Klare 1998 SAJHR 150.

Mayelane v Ngwenyama 20134 SA 415 (CC).

Mayelane v Ngwenyama 20134 SA 415 (CC) para 24.

Keep and Midgley "Emerging Role of Ubuntu-botho" 47-49. 
particular value seeks to achieve, rather than obsessing over its historical origin and it is this approach which they believe makes the process of harmonisation possible. ${ }^{13}$ As will be seen, the Constitutional Court has regularly emphasised the overlap between ubuntu, rights articulated in the Constitution, and emerging international legal norms.

Our paper provides a critical engagement with the evolution of the judicial reception of ubuntu in the courts from the adoption of the 1993 interim Constitution until November 2013. Our contribution could have been synthesised and presented in several different ways. ${ }^{14}$ We have adopted a different approach from those taken by Keep and Midgley and by Bennett. ${ }^{15}$ Instead of following their pattern of discussing the material under the different areas of law, we have chosen to place emphasis on (a) chronology (historical trajectory) and (b) thematic development. We have two aims in making this choice.

First, after noting the importance of the role of ubuntu in the Constitutional Court's first case - $S$ v Makwanyane ${ }^{16}$ - we present a critical commentary that engages with scholarly contributions on the Court's approach in this case. The analysis explains and responds to various criticisms. Thereafter we emphasise a temporal division between the treatment given to ubuntu by the courts before Port Elizabeth Municipality $v$ Various Occupiers ${ }^{17}$ (PE Municipality) and after this important case. We show that PE Municipality led to a wave of ubuntu-inspired judgments that heralded a new era. We also track chronological patterns in respect of particular themes, in particular the link between ubuntu and restorative justice. Charting, analysing and understanding the development of ubuntu in chronological terms is, we submit, a valuable end in itself. It opens up debate about notable temporal developments in the use of the concept of ubuntu. These developments are not

Keep and Midgley "Emerging Role of Ubuntu-botho" 48.

14 It bears mentioning that our approach differs considerably from that taken by Cornell and Muvangua Ubuntu and the Law, which consists of case extracts for two-thirds and a collection of essays for the rest of the book.

15 Bennett 2011 PEL 30-2.

16 S v Makwanyane 19953 SA 391 (CC).

17 Port Elizabeth Municipality v Various Occupiers 20051 SA 217 (CC). 
simply random, but appear to have a pattern. We have attempted, therefore, to make some sense of this. This approach makes possible a picture of the historical trajectory of the use of ubuntu in South African jurisprudence.

Secondly, although ubuntu can be applied to virtually any area of law and hence its development has not always followed a clear thematic path, we think there is scholarly value in emphasising a particular thematic strand in the judicial application of the concept of ubuntu, namely its link to restorative justice. This general theme has been a driving force behind the application of ubuntu to several divergent areas of law, such as criminal law, defamation law and eviction cases. While it is certainly useful to examine these cases in terms of these different areas of law - something we have also done - we believe it is important to analyse the cases within the broader theme of restorative justice. This enables us to highlight the deep connection between these different cases despite their differing areas of law.

In sum, this article argues that ubuntu, whether as a value or a legal norm, is not a technocratic concept. Efforts to pin it down and to contain it within overly strict boundaries or definitions are misguided. Proper understanding of this concept calls for wisdom and open-mindedness. This does not, however, mean that ubuntu has a mercurial nature that changes according to its context. Rather, it is more like humanity in its diversity, and serves to remind us that our diversity should not cover up our humanity, lest we forget.

\section{The judicial birth of ubuntu: $S v$ Makwanyane}

\subsection{The problem of definition}

It is often noted that ubuntu resists easy definition. ${ }^{18}$ It has been described variously as an age-old and traditional African world-view, a set of values or a philosophy of

18 See, for example, Mokgoro 1998 PEL 2-3; Bennett 2011 PEL 30-2; and Himonga 2013 Journal of African Law 173. 
life which plays a strong and defining role in influencing social conduct. ${ }^{19}$ Swartz $^{20}$ says that ubuntu offers a "unifying vision of community built upon compassionate, respectful, interdependent relationships" and that it serves as "a rule of conduct, a social ethic, the moral and spiritual foundation for African societies." Unsurprisingly, then, scholarly and philosophical debates concerning the proper ambit of ubuntu what it does and does not refer to - are frequently complex and highly contested.

Some have argued that it cannot be given expression satisfactorily using non-African vocabulary. Former Constitutional Court Justice Yvonne Mokgoro writes: ${ }^{21}$

The concept ubuntu, like many African concepts, is not easily definable. To define an African notion in a foreign language and from an abstract as opposed to a concrete approach is to defy the very essence of the African world-view and can also be particularly elusive...Because the African world-view cannot be neatly categorised and defined, any definition would only be a simplification of a more expansive, flexible and philosophically accommodative idea.

This issue of language, especially a "foreign language", merits specific comment. We do not agree that the concept is diminished when discussed in a foreign language. In fact if ubuntu is to facilitate transformation and reconciliation as aspired to, then we must be able to discuss it and understand it in what many may regard as "foreign" languages. This state of affairs ought not to be surprising or unacceptable. All abstract notions that form our values and principles must be grappled with through language; indeed, dignity, equality and freedom have been the subject of debate for centuries and will likely continue to be so debated. There is thus no obvious or plausible reason why ubuntu and its scope or content should be exempt from such debate.

Our chief aim is to understand the content given to ubuntu by the South African judiciary, how it has been implemented in application, and the purpose it is serving. Kroeze explains that: ${ }^{22}$

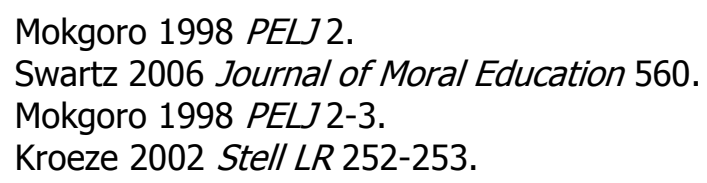


[i]n the legal context the ubuntu concept is used to give content to rights (as a constitutional value) and to limit rights (as part of the values of an open and democratic society). But in the process of functioning within the rights discourse, the concept is also changed.

Presumably this means that once the judiciary begins to interpret a concept within a particular legal setting, its content will inevitably become tied to these interpretations. This might involve a level of change of conceptual content. No judgment has been more notable for its explication of ubuntu as a legal concept than $S$ v Makwanyane, in which the Constitutional Court decided, unanimously, that implementation of the death penalty was unconstitutional. Seventeen years later it is possible to trace the central strands of the subsequent development of the interpretation of ubuntu back to the remarks made in this ruling. The remainder of this section highlights various dimensions of ubuntu identified and explained by different members of the Constitutional Court bench in Makwanyane.

A remarkable feature of the treatment of ubuntu in the jurisprudence thus far is the virtual absence of reference to historical and philosophical writings from Africans about the concept. Whilst not an extensive body of literature, it exists and is thoughtful, analytical and comparative insofar as intra-continental opinions and debates are canvassed. ${ }^{23}$ Consequently, the near-total absence of reference to such writing, especially in Makwanyane, is notable. Even more remarkable, thus, is the enduring value attached to the Constitutional Court's pronouncements on ubuntu in Makwanyane, since a reasonable inference is that these pronouncements were largely subjective and personal views about the concept. South Africa is indeed fortunate to have had such thoughtful, wise and open-minded Justices on the Makwanyane bench.

\subsection{Ubuntu as a constitutional value}

It is appropriate to begin by reflecting on the constitutional status of ubuntu. Makwanyane was decided in terms of the interim Constitution. As explained earlier,

23 It is beyond the scope of this article to engage with that body of literature. 
ubuntu rather than victimisation was aspired to in the post-amble of the interim Constitution. However, until ubuntu was invoked and explained by the courts, it was an open question as to how fundamental or important a notion it should be for the purposes of constitutional interpretation. Justices Madala and Mokgoro addressed this issue in Makwanyane and both attributed to ubuntu a far-reaching and fundamental role in South Africa's constitutional dispensation. The sentiments expressed have proved influential.

Madala J spoke of ubuntu as a "concept that permeates the Constitution generally and more particularly chapter three which embodies the entrenched fundamental human rights." ${ }^{24}$ This is a significant claim, attributing fundamental importance to ubuntu in the context of constitutional reasoning. Mokgoro J made a similar point about ubuntu's legal status, placing it at the forefront of constitutional interpretation. She noted first that, in contrast to the apartheid legal order, in which parliamentary sovereignty demanded conservative and literal statutory interpretation by the judiciary, the post-apartheid order of constitutionalism requires courts to develop and interpret entrenched rights "in terms of a cohesive set of values, ideal to an open and democratic society". ${ }^{25}$ In her view, this interpretation should be inclusive of South Africa's indigenous value systems, which relate closely to the constitutional goal of a society based on dignity, freedom and equality. While acknowledging that a function of the Constitutional Court is to protect the rights of vulnerable minorities, she stated: ${ }^{26}$

In interpreting the Bill of Fundamental Rights and Freedoms, as already mentioned, an all-inclusive value system, or common values in South Africa, can form a basis upon which to develop a South African human rights jurisprudence. Although South Africans have a history of deep divisions characterised by strife and conflict, one shared value and ideal that runs like a golden thread across cultural lines, is the value of ubuntu - a notion now coming to be generally articulated in this country.

Along with Madala J, Mokgoro J believes that ubuntu could serve as a basis from which interpretation of the Bill of Rights could proceed. Both Justices endorsed the 
idea of ubuntu as an over-arching and basic constitutional value, which could drive and assist the Court's future jurisprudence. Although neither Justice expanded on this thought, both made it clear that, in their view, the relevance of ubuntu for South Africa's new order extended well beyond what a narrow reading of its brief appearance in the post-amble of the interim Constitution might have suggested. The claim that it is foundational, permeating the Constitution generally, provided a taste of the Court's future thoughts on the matter.

It became clear in Makwanyane that the status of ubuntu as a constitutional value means that it is an inherently normative notion. Like many other ethically-loaded constitutional concepts - such as "dignity", "freedom", "equality", "inhuman", "cruel", and so on - definitional questions about ubuntu are closely bound up with moral questions. This truism raises further questions about the view that a "foreign language" cannot manage appropriate discussion about ubuntu. It is difficult to facilitate clear understanding about abstract notions in any language. In our view, the task is to strive towards a shared and accepted understanding of ubuntu for the purposes of communication about how to interpret the Bill of Rights and other aspects of a democratic society based on dignity, freedom and equality. This desired understanding may take a long while to emerge concretely.

Consequently, when the judiciary applies ubuntu as a constitutional value, inevitably it attempts to define it to make its normative content clearer for the context under consideration. Explaining the "meaning" of the concept simultaneously involves outlining the values to which it is bound. It is not a purely "descriptive" or nonnormative task.

\subsection{Giving ubuntu content}

We are now ready to ask: what legal content, meaning or "definition" of ubuntu did the Court supply in Makwanyane? As the first judicial pronouncement on the concept, unsurprisingly, the statements were influential on its future development by the courts. We highlight certain generally agreed upon key features of ubuntu: its 
communalism and emphasis on particular social values; its overlap with other key values enshrined in the Bill of Rights; and its emphasis on (re)conciliation.

Madala J was most succinct in his description: ubuntu "carries in it" the ideas of humaneness, social justice and fairness. ${ }^{27}$ Mokgoro $\mathrm{J}$ asserted that: ${ }^{28}$

While [ubuntu] envelops the key values of group solidarity, compassion, respect, human dignity, conformity to basic norms and collective unity, in its fundamental sense it denotes humanity and morality. Its spirit emphasises respect for human dignity, marking a shift from confrontation to conciliation.

Mohamed J was of the opinion that the post-amble's reference to a "need for ubuntu" expresses: ${ }^{29}$

the ethos of an instinctive capacity for and enjoyment of love towards our fellow men and women; the joy and the fulfilment involved in recognizing their innate humanity; the reciprocity this generates in interaction within the collective community; the richness of the creative emotions which it engenders and the moral energies which it releases both in the givers and the society which they serve and are served by.

Mokgoro $\mathrm{J}$ has also said elsewhere that the value of ubuntu has been: ${ }^{30}$

viewed as a basis for a morality of co-operation, compassion, communalism, and concern for the interests of the collective respect for the dignity of personhood, all the time emphasising the virtues of that dignity in social relationships and practices.

As we can see from the statements of Mokgoro and Mohamed JJ, ubuntu is intimately bound up with fundamentally social values. Langa J, highlighting its communal spirit, stated that a culture of ubuntu "places emphasis on communality and on the interdependence of the members of a community". ${ }^{31}$ It recognises the humanity of each person and the entitlement of all people to "unconditional respect, dignity, value and acceptance" from one's community. ${ }^{32}$ Importantly, he continues,

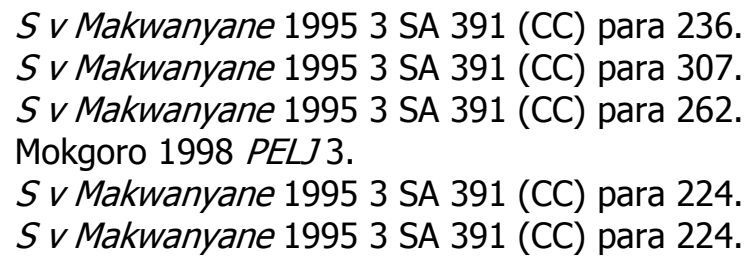


these rights also entail the converse: every person has a corresponding duty to show the same respect, dignity, value and acceptance to each member of that community. Inherent to this communality are the ideas of mutual enjoyment of rights by all, sharing and co-responsibility. ${ }^{33}$

Subsequently, in MEC for Education: KwaZulu-Natal v Pillay, ${ }^{34}$ Langa $\mathrm{C}^{35}$ elaborated on the communal ethos of ubuntu, explaining that the notion that "we are not islands unto ourselves" is central to understanding the individual in African thought. This idea, he said, is regularly expressed by the Zulu phrase umuntu ngumuntu ngabantu, which has been tentatively translated as "a person is a person through other people". ${ }^{36}$ Mokgoro J called this phrasing a "metaphorical" expression, "describing the significance of group solidarity on survival issues so central to the survival of communities". ${ }^{37}$ In MEC for Education: KwaZulu-Natal v Pillay, Langa CJ cites Kwame Gyekye, who says that "an individual human person cannot develop and achieve the fullness of his/her potential without the concrete act of relating to other individual persons". 38

In Makwanyane, Langa $\mathrm{J}^{39}$ raised another significant aspect, namely the extent to which ubuntu overlaps with other important constitutionally-entrenched rights. He stated that an "outstanding feature" of ubuntu is the value it puts on life and human dignity. Ubuntu signifies emphatically that "the life of another person is at least as valuable as one's own" and that "respect for the dignity of every person is integral to this concept". ${ }^{40}$ He remarked: ${ }^{41}$

During violent conflicts and times when violent crime is rife, distraught members of society decry the loss of ubuntu. Thus heinous crimes are the antithesis of ubuntu. Treatment that is cruel, inhuman or degrading is bereft of ubuntu.

S v Makwanyane 19953 SA 391 (CC) para 224.

MEC for Education: Kwazulu-Natal v Pillay 20081 SA 474 (CC) para 53.

By then Langa $\mathrm{CJ}$ was Chief Justice.

MEC for Education: Kwazulu-Natal v Pillay 20081 SA 474 (CC) para 53. See also Mokgoro 1998 PELU2.

$37 \quad$ S v Makwanyane 19953 SA 391 (CC) para 307.

38 MEC for Education: Kwazulu-Natal v Pillay 20081 SA 474 (CC) para 53.

39 As he then was.

40 S v Makwanyane 19953 SA 391 (CC) para 225.

$41 \quad$ S v Makwanyane 19953 SA 391 (CC) para 225. 
For Langa J, therefore, the call for a "return to Ubuntu" was specifically a response to "a background of the loss of respect for human life"; ${ }^{42}$ consequently, it is not difficult to see how embracing ubuntu inevitably shaped his rejection of the constitutionality of the death penalty.

Life and dignity are "like two sides of the same coin" and "the concept of ubuntu embodies them both," according to Mokgoro J. ${ }^{43}$ She cited with approval the statement in the preamble of the International Covenant on Civil and Political Rights, that "human rights derive from the inherent dignity of the human person "44 She then stated: "This, in my view, is not different from what the spirit of ubuntu embraces." 45

A final outstanding feature of ubuntu is the emphasis it places on reconciliation as opposed to punishment or retribution. This was clearly an important factor for the Constitutional Court Justices in considering the acceptability of the death penalty. In the course of providing reasons for its unconstitutionality, Chaskalson P reaffirmed the need for South African society to be consonant with the value of ubuntu, which in the interim Constitution was contrasted with "victimisation". Citing Brennan J in the US Supreme Court in Furman v Georgia, Chaskalson P explained that, in order for society to live up to this aspiration, it "should be a society that wishes to prevent crime...[not] to kill criminals simply to get even with them". ${ }^{46}$ This reasoning fits with the view that the death penalty lies at the furthest extreme of a scheme of retributive justice and that a value system which emphasises reconciliation or forgiveness pulls us away from this extreme.

The link between ubuntu and reconciliation was more explicitly explained by Madala J. ${ }^{47}$ The "reformative" theory of punishment regards punishment as the means to reform and rehabilitate a criminal. This reformative process "accords fully with the 
concept of ubuntu which is so well enunciated in the Constitution." ${ }^{48}$ As will be seen, these comments anticipated much of the ubuntu jurisprudence to follow in the vein of what is now generally termed "restorative" justice. In a poignant passage, he writes of criminals who might find themselves on death row that: ${ }^{49}$

It is true that they might have shown no mercy at all to their victims, but we do not and should not take our standards and values from the murderer. We must, on the other hand, impose our standards and values on the murderer.

For Madala J, one of these values is ubuntu.

In the next section, we engage with criticisms levelled at ubuntu as a legal concept, as explicated by the Constitutional Court Justices, insofar as the concept appears to defy definition or to distinguish itself clearly from other values enshrined in the Bill of Rights.

\section{Critical commentary}

\subsection{Ambiguity debates}

Critics sometimes complain that the concept of ubuntu is insufficiently or too vaguely defined; that it is capable of multiple interpretations and is thus ambiguous. This criticism has emerged both within and outside the legal sphere. ${ }^{50}$

It is a precondition for the efficacy of ubuntu as a legal concept that judges - who may or not have acquaintance with ubuntu as a personal value-system - are able to digest its normative force and apply it to particular scenarios. If the content of ubuntu were ambiguous, it may be difficult for judges or lawyers to draw on it confidently. It would also seem to invite inconsistent or unpredictable applications of the concept.

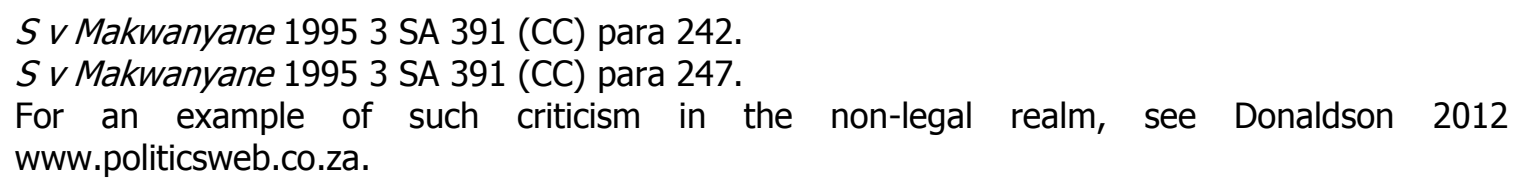




\subsubsection{Must we choose between mutually-exclusive interpretations of ubuntu?}

English argues that ubuntu is ambiguous, owing to the fact that we are made to choose between conflicting and mutually-exclusive interpretations of ubuntu. She says: ${ }^{51}$

The problem is that ubuntu is at once under explained and over explained. To make any sense of the idea, you have to pick and choose between conflicting interpretations.

To take an example, she claims that it cannot concurrently mean both "individual human dignity" and "conformity to basic norms and collective unity", though both notions are said to be strongly associated with ubuntu. By way of justification, she asserts: ${ }^{52}$

These are plainly not the same thing. In fact they can be quite opposite things, as the Soviet Union and Eastern bloc regions have shown us.

It is not clear whether English regards "individual human dignity" and "conformity to basic norms and collective unity" as mutually-exclusive interpretations of ubuntu just because they are "plainly not the same thing" or because they are irreconcilable in a normative sense (ie they are incompatible values which cannot be promoted at once). The reference to the Soviet Union and Eastern bloc might suggest the latter. In our view, there is no reason to think that these two things being plainly not the same means we need to choose between them in giving meaning to ubuntu.

This point warrants reflection. No contradiction is inherent in the idea that normative concepts like ubuntu encompass different values simultaneously. As Justice Mokgoro put it: ubuntu "envelops" various other key values, such as compassion, group solidarity and respect. ${ }^{53}$ Madala J explained that the concept "carries in it" the ideas of humaneness, social justice and fairness. ${ }^{54}$ Social justice is not the same thing as

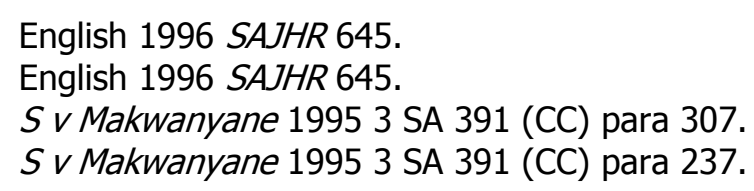


love. Compassion is not the same thing as sharing. There seems nothing particularly problematic about a philosophy or over-arching value concurrently promoting social justice, love, compassion and sharing. In this sense, these traits are not mutually exclusive. Suppose that ubuntu indeed denoted a communal morality, it would be plausible that co-responsibility, social justice, compassion, love and sharing are all values which make up its composition.

English's criticism about the ambiguity of its meaning might rather be that these values necessarily clash in a normative-political sense - that they cannot all be promoted simultaneously - which, if true, could be said to render the normative force of ubuntu irreconcilably contradictory. The ambiguity of ubuntu would follow from the fact that we are given no direction as to which mutually exclusive interpretation is to be preferred. However, as will become evident, the ubuntur inspired jurisprudence indeed points in the direction of the realisation of a democratic society based on dignity, freedom and equality.

\subsubsection{Is ubuntu an empty concept?}

Another criticism is that the Constitutional Court's terms for defining ubuntu in Makwanyane are "by and large" empty, ${ }^{55}$ in that they have no "self-evident meaning". ${ }^{56}$ Kroeze says that no words possess meaning "in and of themselves" and that meaning is always context-dependent. ${ }^{57}$ She then says that the central failure of the Constitutional Court's definitions is that "they are over-loaded with empty concepts". 58

We might accept the claim that terms derive their meaning from specific linguistic contexts; but in our view this is part of the reason that the terms are not empty. We submit that they can be legitimately and meaningfully employed by judges. It is difficult to see why words like humaneness, compassion or dignity are emptier than

Kroeze 2002 Stell $L R 260$ (our emphasis).

Kroeze 2002 Stell LR 260-261.

Kroeze 2002 Stell LR 261.

Kroeze 2002 Stell LR 261. 
any other terms. The fact that abstract notions are difficult to explain does not make them empty.

\subsubsection{Valid concerns about ambiguity}

It is important that a legal concept is not so open-ended that it can be exploited to serve any conceivable purpose. Again, this is especially true of concepts that may be unfamiliar to those tasked with applying them. A normative legal notion must be articulated in enough detail or specificity to ensure that different judges apply the concept similarly. Justice Mokgoro summed up ubuntu as simply being "morality".59 But clearly ubuntu does not embody just any morality. We know that ubuntu places emphasis on some values rather than others. Describing it as simply "morality" therefore seems unhelpful and leaves ubuntu at its most ambiguous. Still, lengthy lists of values which ubuntu "envelops" may unfortunately also be unhelpful in providing the concept with an adequately precise legal valence. One might still complain that the significant generality of this set of values renders the normative content of ubuntu still largely unspecified, vague and ambiguous. Kroeze seems to have this concern in mind when, after noting the difficulty of defining ubuntu, she writes: ${ }^{60}$

... ubuntu is said to include the following values: communality, respect, dignity, value, acceptance, sharing, co-responsibility, humaneness, social justice, fairness, personhood, morality, group solidarity, compassion, joy, love, fulfilment, conciliation, et cetera. The problem with this kind of "bloated" concept is that it tries to do too much. The concept simply collapses under the weight of expectations!

Kroeze's notion of "bloatedness" presumably tries to capture the idea that by being said to include such a wide range of values, the normative content of ubuntu remains ambiguous unless elaborated with greater specificity. Over-explanation, as English noted, might therefore create ambiguity just as much as under- 
explanation. ${ }^{61}$ These worries certainly seem real, as will become even clearer when we consider the alleged redundancy of ubuntu.

The content of value concepts is often contested. ${ }^{62}$ In the context of constitutional interpretation, fleshing out the ambit of freedom, equality or dignity necessitates regard for normative considerations, which are inherently contentious. However, this process does not imply that the concepts being contested are empty. Nor does it imply that attempts to elaborate these concepts close down debate or that the debates themselves lack objective worth. That constitutional values are adaptable, contested, evolving and somewhat open-ended is partly what gives the Constitution its flexibility and transformative power.

In the context of ubuntu, Mokgoro J makes this point when she argues that the lack of specificity of ubuntu is in fact an asset. The more open and flexible this concept is, the greater its potential as a tool for the transformation of South African society. ${ }^{63}$ Similarly, Bennett explains that given that South Africa is in the process of "forging new values", it "would be to impose a premature restriction on its function" if one demanded a precise definition of ubuntu at this stage. ${ }^{64}$

Himonga takes this argument further, suggesting that: ${ }^{65}$

the lack of precise meaning of Ubuntu is consistent with its nature as a value of the South African Constitution....Like other constitutional values, ubuntu can only be conceived of in abstract terms. On this basis, it is only necessary to identify ubuntu's key interrelated attributes: the idea of community, interdependence, dignity, solidarity, responsibility and ideal.

A balance therefore is needed between the extremes of a fine-grained and technical definition and a concept so open-ended as to be meaningless and unhelpful. Ubuntu is not a term of art, like "wrongfulness" or "administrative action", that requires

\footnotetext{
61 English 1996 SAJHR 645.

62 See Gallie 1956 Proceedings of the Aristotelian Society 169.

63 See Himonga 2013 Journal of African Law 173.

64 Bennett 2011 PEL 47.

65 Himonga 2013 Journal of African Law 173, citing a speech Mokgoro delivered at the Future of the Ubuntu Project Workshop, Pretoria, University of Pretoria on 19 August 2010.
} 
careful definition to ensure appropriate application in law. Ubuntu is a way of seeing ourselves and of articulating how we should behave. Exactly which components fit in particular scenarios depends on the scenario. Necessarily, thus, it would be counterproductive to strive for a technical definition that would close its current open-ended description.

\subsection{Redundancy debates}

\subsubsection{How unique is ubuntu?}

We now turn to the criticism that ubuntu is redundant to constitutional interpretation. Some regard ubuntu as simply an African version of communalism, leading them to question the reason for invoking it in a modern constitutional context. An example to support this view may be found in Makwanyane where Chaskalson P quoted the United States Supreme Court in Furman v Georgia, saying that, to embody the value of ubuntu, South African society needed to live up to Justice Brennan's call for a society that "wishes to prevent crime ... [not] to kill criminals simply to get even with them. ${ }^{166}$ Chaskalson $\mathrm{P}$ does not explain the relationship between the American jurisprudence and ubuntu, leading to the following comment: ${ }^{67}$

This leaves one with an interesting dilemma. On the one hand, Chaskalson's judgement leaves the impression that the values of ubuntu are basically the same as those in American jurisprudence. In which case it raises the question of exactly why it is then necessary to refer to ubuntu at all. On the other hand, it might be that there are differences, which begs the question as to why the American case is quoted at all.

Unless the concept of ubuntu is distinguished from other concepts by explicating its unique content, an objection of redundancy can be raised. If the courts can do their job adequately without raising ubuntu, why raise it in the first place? On this view, the application of ubuntu must stimulate fresh or novel modes of judicial thought and have an actual impact on case outcomes for its introduction to be justified and its continuation expected.

$66 \quad S$ v Makwanyane 19953 SA 391 (CC) para 131.

67 Kroeze 2002 Stell LR 253. 
It is worth pointing out that the redundancy objection can be raised also in respect of the Constitutional Court's insistence on the close connection between ubuntu and other concepts in the Constitution. We have seen in Makwanyane how Justices Mokgoro and Langa argued that ubuntu is closely bound up with the right to life and the right to dignity. Again, the need for ubuntu might be questioned if the Constitution already contains other concepts that express the same values. Bennett counters this stance on the basis that ${ }^{68}$

[t]he Western conception of dignity envisages the individual as the right-bearer, whereas ubuntu sees the individual as embedded in a community.

It is unlikely that such a response would satisfy all critics. Again, unless the unique content of ubuntu is circumscribed with precision, its legal status is, in certain respects, unclear and largely inert. According to Kroeze, the question of how the open-ended understanding of ubuntu might affect the interpretation of key terms in the Constitution is left unanswered. ${ }^{69}$ Thus, she asserts: ${ }^{70}$

There is no indication that the emphasis on communality in any way changes the typically liberalist concept of dignity.

Similarly, even if one were to accept that ubuntu regards the individual as "embedded in a community", one could still argue that, unless the details of this are fleshed out, the charge that ubuntu is redundant remains unrebutted.

The interrelatedness of the ambiguity and redundancy objections are easy to appreciate: most critics hold the view that only once the content of ubuntu is made clear and unambiguous will the question of its redundancy be answerable. Similarly, one cannot easily assess the extent to which ubuntu overlaps with other concepts unless one has clarity about its content. We will return to this point when we consider the possible conflict between ubuntu and the Bill of Rights. 


\subsubsection{A response to the redundancy objection}

Keep and Midgley anticipate the redundancy objection. Given their position on the pressing need to legitimate the post-apartheid constitutional order, it is unsurprising that they say that the redundancy objection is misguided. ${ }^{71}$ It is vital, they argue, that South Africa's jurisprudence should come to reflect the diverse value systems of the population. As harmonisation of Western and African values is the best way to achieve this, they see the overlap between ubuntu and the Bill of Rights as ideal. ${ }^{72}$ It might be pointed out that there is something very powerful about having one's judicial reasoning reinforced by two separate value systems.

This seems like a plausible possible response to the redundancy objection. Although considerable efforts were made to involve the public in the drafting process of the Constitution, the need remains to further legitimate it in the eyes of the majority of South Africa's citizens. However, whether or not a technical argument that ubuntu is redundant to constitutional interpretation is persuasive is not in our view the point. Rather, the African-ness of its name; that it is not tied to Western origins; that it is not associated with a particular religious dogma or philosophy; and, above all, that ubuntu is inclusive, aspirational and also accessible; all of these seem to make it an ideal worth striving for in post-apartheid South Africa. Consequently, our view is that, even if the redundancy objection is supported, its redundancy would not necessarily rule out the importance of ubuntu in South African law.

\section{Ubuntu's expansion: from Makwanyane to PE Municipality}

After Makwanyane but before PE Municipality only a few cases further developed or explained ubuntu as a South African legal concept. A temporal division between Makwanyane and the Constitutional Court's judgment in Port Elizabeth Municipality v Various Occupiers ${ }^{73}$ in October 2004 is appropriate because, in our view, this case marked the beginning of a new dawn for ubuntu-based jurisprudence. It is the most

\footnotetext{
Keep and Midgley "Emerging Role of Ubuntu-botho" 48.

Keep and Midgley "Emerging Role of Ubuntu-botho" 48.

Port Elizabeth Municipality v Various Occupiers 20051 SA 217 (CC).
} 
important post-Makwanyane case in respect of its use of ubuntu. Prior to this (but post-Makwanyane), significant cases that provided substantive legal development of ubuntu include Bophuthatswana Broadcasting Corporation $v$ Ramosa, ${ }^{74} S \mathrm{v}$ Mandela, ${ }^{75}$ Crossley $v$ The National Commissioner of the South African Police Services ${ }^{76}$ and Du Plooy $v$ Minister of Correctional Services. ${ }^{77}$

Helpful analysis and discussion is provided in Bophuthatswana Broadcasting Corporation $v$ Ramosa. In response to the argument that constitutional rights to protest and demonstrate were not subject to the rights of others, Khumalo J examined ubuntu, explaining that two complementary maxims - one from Confucius and the other from St Matthew's version of the Gospel - form part of ubuntu. ${ }^{78}$ Confucius said: "Do not do unto others what you would not want others to do unto you," while the Gospel according to St Matthew says that which you would like others to do to you, you should do for them. ${ }^{79}$ Khumalo J refers also to Justinian: "the precepts of the law are these: to hurt no one, to give everyone his due."

With these principles in mind, he held that the respondents' intended method of protesting would interfere in a way which could not be construed as "the proper exercise of a right". ${ }^{80}$ The helpfulness of this analysis lies in the linking of ubuntu to maxims like the Golden Rule. Khumalo J reminds us that ubuntu overlaps with other key ethical and legal notions. Just as the Makwanyane court was at pains to emphasise how the values of ubuntu harmonise with and augment other values in the Bill of Rights, Khumalo J asserted that ubuntu echoes many historical principles of law and ethics, which still today play a role in guiding the judiciary.

Keep and Midgley, it will be recalled, argue that the usefulness and importance of ubuntu in the South African legal context derive partly from its ability to harmonise

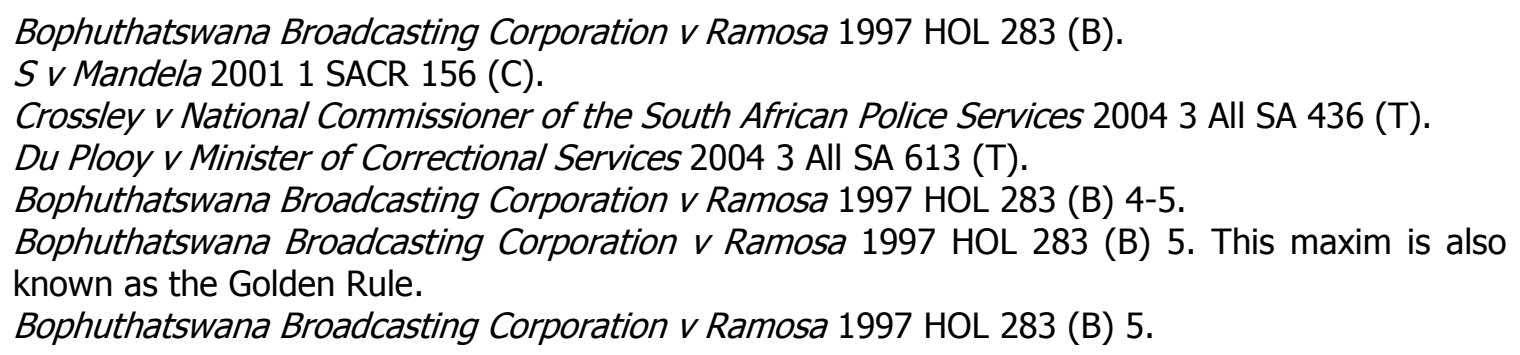


Western and African values. The analysis of Khumalo J provides an exemplar of the sort of harmonisation which Keep and Midgley may have had in mind.

In a different context, the judiciary was also paying attention to the possible influence of ubuntu on previously unquestioned ways of dealing with matters. In $S v$ Mandela, ${ }^{81}$ the question was whether an accused could rely on necessity as a complete defence to murder charges. This involved an "exquisite balance" of "this most precious of rights" (the right to life) ${ }^{82}$ Citing the "current climate of violence and blatant disregard for human life" pervasive in South Africa, the Court stated that perhaps good reason existed to limit the defence of necessity to cases where life was threatened: ${ }^{83}$

In circumstances where the danger of death cannot be averted, save by acts of heroism which extend beyond the capacity that should, and can, be demanded of the reasonable person.

In holding that Mandela fell short of this standard, Davis J went on to say: ${ }^{84}$

Were a court to accept so low a standard in finding the existence of such a defence it would be guilty of demanding very little from members of our society, which is now a constitutional community, based on fundamental principles including those of freedom, dignity, ubuntu and respect for life. Were the defence of necessity to be extended as far as Mr Vismer urges, it would represent a lowering of regard for life and an undermining of the very fabric of the attempt to build a constitutional community, where each and every person is deserving of equal concern and respect and in which community grows sourced in the principle of ubuntu.

This final remark echoes the comments made by Langa $\mathrm{J}$ in Makwanyane regarding the link between ubuntu and the principle of giving all human beings their due. ${ }^{85} \mathrm{~S} v$ Mandela also again illustrates the overlap between the demands of ubuntu and those of the Bill of Rights, such as the right to life.

\footnotetext{
$81 S$ v Mandela 20011 SACR 156 (C). Note that the accused was not the former President Nelson Mandela.

82 S v Mandela 20011 SACR 156 (C) 167C.

$83 \quad S$ v Mandela 20011 SACR 156 (C) 167C-D.

$84 \quad S$ v Mandela 20011 SACR 156 (C) 168A-C.

85 S v Makwanyane 19953 SA 391 (CC) para 225.
} 
In Crossley $v$ The National Commissioner of the South African Police Services ${ }^{86}$ the SAPS sought an interdict to prevent the burial of the man the accused were alleged to have murdered, so that a forensic examination of the remains could be undertaken. The counter-argument was that African customary practices dictated burial without delay to prevent infringement of the rights to dignity and to freely practise religion, as per sections 10 and 15 of the Constitution respectively. Patel J accepted the right to adduce and challenge evidence as a key component of a fair trial but noted also that: ${ }^{87}$

if every accused person came to Court on an urgent basis that his/her right to a fair trial is likely to be jeopardised because a crucial piece of evidence needs to be preserved, then in reality the effectiveness of the criminal justice system will be undermined.

More significantly, he upheld the vital importance of having one's dignity respected and the right to freely practise one's religion. ${ }^{88}$ He cited Bührmann $v$ Nkosi and Another, ${ }^{89}$ which emphasised the "strong relationship between people's religion and the way in which, in the manifestation of such a belief, they would want their dead to be buried". In contrast to pre-1994 South African society, when African customary and religious practices generally were neglected by the legal system, under the current Constitution: ${ }^{90}$

[t]he burial of the deceased in accordance with African religious custom must surely prevail. It accords credence to the very essence of the dignity, not only to the deceased's immediate family, relatives and community but also the deceased himself.

Patel J noted that the essential basis to the Constitution and South Africa's democracy was ubuntu. In this context, Patel J held that "the higher constitutional

86 Crossley v National Commissioner of the South African Police Services 20043 All SA 436 (T).

87 Crossley v National Commissioner of the South African Police Services 20043 All SA 436 (T) para 12.

88 Crossley v National Commissioner of the South African Police Services 20043 All SA 436 (T) paras 13-18.

89 Bührmann v Nkosi 19994 All SA 337 (T) 353.

90 Crossley v National Commissioner of the South African Police Services 20043 All SA 436 (T) para 18. 
value of the right to dignity" applies to both the living and the departed, and he therefore dismissed the application. ${ }^{91}$

An obvious parallel exists between the post-apartheid recognition of African customary law and the protection of indigenous practices, on the one hand, and the embrace of ubuntu as a legal concept, on the other. The legal system does not just recognise and apply customary law and embrace it alongside non-customary law. As Sachs J explained in Makwanyane, the courts can and should look to African legal traditions as sources of law capable of guiding our general constitutional jurisprudence: ${ }^{92}$

The secure and progressive development of our legal system demands that it draw the best from all the streams of justice in our country.... Above all, however, it means giving long overdue recognition to African law and legal thinking as a source of legal ideas, values and practice. We cannot, unfortunately, extend the equality principle backwards in time to remove the humiliations and indignities suffered by past generations, but we can restore dignity to ideas and values that have long been suppressed or marginalized.

In the same month as Crossley, Patel J presided over Du Plooy v Minister of Correctional Services, ${ }^{93}$ in which ubuntu again played an important role in the judgment of the Transvaal High Court. In this case, which involved the rightness of refusing parole on medical grounds to a terminally ill prisoner, Patel $\mathrm{J}$ found the decision to refuse parole to be irrational and in contravention of the Correctional Services $A c t^{4}$ as well as several provisions of the Constitution. ${ }^{95}$ He stated that the applicant was: ${ }^{96}$

in need of humanness, empathy and compassion. These are values inherently embodied in ubuntu. When these values are weighed against the applicant's continued imprisonment, then, in my view, his continued incarceration violates his human dignity and security, and the very punishment itself becomes cruel, inhuman and degrading.

91 Crossley v National Commissioner of the South African Police Services 20043 All SA 436 (T) paras 19-20.

92 S v Makwanyane 19953 SA 391 (CC) paras 365-366.

93 Du Plooy v Minister of Correctional Services 20043 All SA 613 (T).

94 Correctional Services Act 8 of 1959.

95 Du Plooy v Minister of Correctional Services 20043 All SA 613 (T) para 27.

96 Du Plooy v Minister of Correctional Services 20043 All SA 613 (T) para 29. 
Again, ubuntu served to augment a constitutional interpretation, reflecting its role as part of the "essence" of South Africa's post-apartheid democracy, permeating constitutional interpretation generally.

It is worth pointing out that in this matter ubuntu was invoked in the name of compassion, being viewed as an end in itself, rather than as a means to a reformative end, as was the case in both Makwanyane and Mandela. The prisoner was eligible for compassionate treatment that looked past his status as a convicted wrongdoer. The basis for this was, in the court's view, to be found in the conciliatory aspect of ubuntu. Of course, other ethical principles would admit of such a view too, like compassion itself, and charity, which is celebrated in the teachings of most major religions. However, the attractiveness of ubuntu lies in its not being associated with a particular religion, and thus it poses no threat to sensitivities on that front. The view expressed by Patel J should not be understood to mean that incarceration itself violates dignity unjustifiably. Rather it was the presence of the terminal illness that tipped the balance towards compassion. This insight helps to explain the outrage of many South Africans at the perceived perverse manipulation of ubuntu and compassion in the cases of Schabir Shaik and Jackie Selebi. Both these men were paroled on the basis that they were terminally ill; yet both seem to have made miraculous recoveries, judging by their activities observed by the public since their release from prison.

\section{$5 \quad$ Ubuntu and restorative justice}

\subsection{PE Municipality: eviction, ubuntu and restorative justice}

Although, important developments involving the use of ubuntu occurred in the lower courts after Makwanyane, it was not until PE Municipality $v$ Various Occupiers ${ }^{97}$ in 2004 that the concept received substantial treatment by the Constitutional Court. ${ }^{98}$

Port Elizabeth Municipality v Various Occupiers 20051 SA 217 (CC).

Note that Port Elizabeth Municipality was handed down two weeks before the Constitutional Court's verdict in Bhe, which, as will be seen later, also included some noteworthy statements regarding ubuntu. 
This case marked the beginning of the Court's emphasis on the close connection between ubuntu and restorative justice, even though this latter phrase was not used in the case. It also set in motion an influential strand of ubuntu-based jurisprudence in eviction matters. Keep and Midgley say that the focus of ubuntu on community and "dignity-through-others" means that we should not be surprised by the influence of ubuntu in this area. ${ }^{99}$ Eviction and sentencing cases have been most influenced by this emphasis on restorative justice. However, as will be seen, restorative justice fits into many different situations and it is likely that only the early stages of exploring its various possible applications have been seen thus far.

In PE Municipality the Court was required to balance the occupiers' right to access adequate housing and their right not to be unlawfully evicted from their homes, on the one hand, with the landowner's property rights, on the other. ${ }^{100}$ Sections 25 and 26 of the Constitution (concerned with property rights and housing rights respectively), together with the Prevention of Illegal Eviction and Unlawful Occupation of Land Act (PIE), ${ }^{101}$ provide the constitutional and statutory context for this delicate balancing act.

Sachs J, writing for an unanimous Court, explained that sections 25 and 26 of the Bill of Rights and PIE required the balancing of the competing interests of both unlawful occupiers and owners in a "principled way" to promote "the constitutional vision of a caring society based on good neighbourliness and shared concern". ${ }^{102}$

Adding to the founding values expressly prescribed by the Constitution, Sachs J asserted that: ${ }^{103}$

[t]he Constitution and PIE confirm that we are not islands unto ourselves. The spirit of ubuntu, part of the deep cultural heritage of the majority of the population, suffuses the whole constitutional order. It combines individual rights with a communitarian philosophy. It is a unifying motif of the Bill of Rights, which is

\footnotetext{
99 Keep and Midgley "Emerging Role of Ubuntu-botho" 43.

100 Port Elizabeth Municipality v Various Occupiers 20051 SA 217 (CC) para 13.

101 Prevention of Illegal Eviction and Unlawful Occupation of Land Act 19 of 1998.

102 Port Elizabeth Municipality v Various Occupiers 20051 SA 217 (CC) para 37.

103 Port Elizabeth Municipality v Various Occupiers 20051 SA 217 (CC) para 37.
} 
nothing if not a structured, institutionalised and operational declaration in our evolving new society of the need for human interdependence, respect and concern.

Sachs J elaborated on the content of ubuntu by expanding on the assertions in Makwanyane by Mokgoro and Madala Jj, viz that ubuntu permeates the constitutional order, calling it a "unifying motif of the Bill of Rights". He affirmed the need for bona fide engagement with the parties to find "mutually acceptable solutions" to legal disputes, ${ }^{104}$ reasoning that in eviction cases it was no longer constitutionally acceptable to regard people as "faceless and anonymous squatters" that should "automatically...be expelled as obnoxious social nuisances". ${ }^{105}$

The complex socio-economic problems that underlie unlawful occupation of land require instead that unlawful occupiers be treated with respect and that their views should be heard. ${ }^{106}$ Given the constitutional obligation on the State to facilitate access to housing as well as to facilitate the protection of private property interests, it is particularly expected that the State will pay careful attention to the expectation for procedural and substantive justice, as outlined in PIE. Sachs J explained that courts should be cautious to find a request for eviction to be just and equitable where it is "not satisfied that all reasonable steps had been taken to get an agreed, mediated solution". ${ }^{107}$

\subsection{The link between PE Municipality and restorative justice}

In criminal law cases, restorative justice has been described as: ${ }^{108}$

an approach to justice that focuses on repairing the harm caused by crime while holding the offender responsible for his or her actions, by providing an opportunity for the parties directly affected by the crime - victim(s), offender and community to identify and address their needs in the aftermath of the crime, and seek a resolution that affords healing, reparation and reintegration, and prevents further harm.

\footnotetext{
104 Port Elizabeth Municipality v Various Occupiers 20051 SA 217 (CC) para 39.

105 Port Elizabeth Municipality v Various Occupiers 20051 SA 217 (CC) para 41.

106 Port Elizabeth Municipality v Various Occupiers 20051 SA 217 (CC) para 29.

107 Port Elizabeth Municipality v Various Occupiers 20051 SA 217 (CC) para 61 (our emphasis).

108 See $S$ v Maluleke 20081 SACR 49 (T) para 28.
} 
Although a familiar approach in this context in recent years, the idea of restorative justice is not confined to criminal law. Skelton points out that: ${ }^{109}$

[r]estorative justice has a special resonance with African customary law processes, where disputes are treated in much the same way whether they are civil or criminal, and this tendency to avoid a strong distinction between civil and criminal wrongs is also a feature of restorative justice. Acceptance of responsibility, making restitution and promoting harmony are the key outcomes desired in all kinds of disputes.

She further notes that while Sachs ] did not refer explicitly to "restorative justice" in PE Municipality, by advocating mediation, dialogue, compromise and reintegration into the community, his judgment arguably reflects this notion. ${ }^{110}$ Indeed, this judgment may be regarded as a seminal example of the application of restorative justice principles. Of course, insofar as this approach is closely linked to an application of ubuntu, we should not be surprised. The reader will recall the link between ubuntu and rehabilitation recognised in the interim Constitution and in the comments by Madala J in Makwanyane, which emphasise the relationship between ubuntu and the "reformative" theory of punishment. ${ }^{111}$

\subsection{The restorative justice approach in criminal law}

As we will see shortly, Mokgoro and Sachs JJ were more explicit in drawing the connection between ubuntu and restorative justice in Dikoko $v$ Mokhatla. ${ }^{112}$ However by this time (August 2006), restorative justice had become an increasingly familiar approach in the context of criminal law. Two cases are important in this regard. Cornell and Muvangua have argued that they resonate with the values of ubuntu, even though neither explicitly refers to the concept. ${ }^{113}$

\footnotetext{
Skelton 2010 SAPL 95.

Skelton 2010 SAPL 98.

S v Makwanyane 19953 SA 391 (CC) para 241.

Dikoko v Mokhatla 20066 SA 235 (CC).

Cornell and Muvangua Ubuntu and the Law 14-15.
} 
$S v$ Shilubane ${ }^{114}$ dealt with the appropriateness of a sentence for a factual scenario that involved the theft of property to the value of R216, for which offence a sentence of nine months' imprisonment was handed down. Taking the whole context into account, including the accused's previously clean record and his genuine remorse, Bosielo J found the sentence to be "disturbingly inappropriate". He emphasised the virtues of restorative justice in the light of empirical evidence in support of the view that retributive justice fails to curb increasing crime levels and that the latter is ${ }^{115}$

counter-productive if not self-defeating ... to expose an accused like the one, in casu, to the corrosive and brutalising effect of prison life for such a trifling offence.

He argued for serious consideration of alternative sentences like community service when the accused does not pose a serious danger to society. ${ }^{116}$ These remarks reflect the conciliatory aspects of ubuntu, which are also reflective of restorative justice.

A sentence for a murder conviction was under consideration in $S v$ Maluleke, ${ }_{1}^{117}$ Bertelsmann J found several mitigating factors that were relevant to sentencing, including that the accused was not a danger to society and had demonstrated remorse. He explained, similarly to Bosielo J, that incarceration is not the only option. Community service, in conjunction with suitable conditions, is an alternative. ${ }^{118}$ He considered the motivation for introducing restorative justice measures into South Africa's legal system and noted that countries like New Zealand and Canada have drawn on their indigenous cultures to improve their respective criminal justice systems. ${ }^{119}$

Bertelsmann J commented that several restorative justice principles can be located within traditional African practices: the emphasis on reincorporating offenders into

\footnotetext{
114 S v Shilubane 20081 SACR $295(T)$.

115 S v Shilubane 20081 SACR 295 (T) paras 5-6.

$116 S$ v Shilubane 20081 SACR 295 (T) para 6.

117 S v Maluleke 20081 SACR 49 (T).

118 S v Maluleke 20081 SACR 49 (T) para 12.

$119 S$ v Maluleke 20081 SACR 49 (T) para 30.
} 
the community after their shaming and an expression of repugnance towards the act by the offenders; the avoidance of the prolonged segregation or marginalisation of offenders; and the community-based focus on reconciliation between the parties and the restoration of harmonious relations after the conflict. ${ }^{120}$ He noted that Shilubane was to date the only South African case to evidence a "conscious recognition of the advantages of restorative justice". ${ }^{121}$ He found that: ${ }^{122}$

restorative justice, properly considered and applied, may make a significant contribution in combating recidivism by encouraging offenders to take responsibility for their actions and assist the process of their ultimate reintegration into society thereby. ... In addition, restorative justice, seen in the context of an innovative approach to sentencing, may become an important tool in reconciling the victim and the offender and the community and the offender. It may provide a whole range of supple alternatives to imprisonment. This would ease the burden on our overcrowded correctional institutions.

Although Bertelsmann J did not explicitly mention ubuntu in Maluleke, he endorsed the consideration of the principles of restorative justice in the sentencing proceedings in $S v$ Sibiya, ${ }^{123}$ this time explicitly referring to ubuntu. The accused had breached a Protection Order while serving a suspended sentence for a domestic violence conviction. The magistrate regarded direct imprisonment as the only appropriate sentence. Bertelsmann J rejected this view. Serving time in jail would lead to the loss of the offender's job, which would be detrimental to him, his dependants and society. ${ }^{124}$ Furthermore, imprisonment would expose him to the company of "experienced criminals", which exposure was likely to cause more harm than good. ${ }^{125}$ Bertelsmann J held that a suspended sentence would have been more appropriate and would have been ${ }^{126}$

based upon an application of the principles of ubuntu by effecting a reconciliation between the victim and the offender.

\footnotetext{
$120 \quad$ S v Maluleke 20081 SACR $49(\mathrm{~T})$ para 30.

$121 S$ v Maluleke 20081 SACR 49 (T) para 32. Readers wondering how a 2008 reported case was available to Bertelsmann $\mathrm{J}$ in 2006 should note that $S v$ Shilubane was decided in 2005 but reported only in 2008.

122 S v Maluleke 20081 SACR $49(\mathrm{~T})$ paras 33-34.

123 S v Sibiya 20101 SACR 284 (GNP).

124 S v Sibiya 20101 SACR 284 (GNP) para 11.

$125 S$ v Sibiya 20101 SACR 284 (GNP) para 10.

$126 \quad S$ v Sibiya 20101 SACR 284 (GNP) para 13.
} 
In Van Vuren $v$ Minister of Correctional Services ${ }^{127}$ the Constitutional Court considered an application for relief, including a mandamus ordering consideration of possible placement on parole. The prisoner was subject to a commuted life sentence after Makwanyane held the death penalty to be unconstitutional. The Court decided that the applicant should be considered for placement under community correction ${ }^{128}$ on the basis that: ${ }^{129}$

Restorative justice, in our jurisprudence, is linked to the foundational value or norm of Ubuntu-Botho. It is a value that recognises - in the context of this case - that to rehabilitate an offender sentenced to life incarceration to a position where he or she is repossessed of the fuller scope of his or her rights, is to recognise the inherent human dignity of the individual offender.

Parole, the Court found, has a restorative justice aim. It seeks to rehabilitate and reconcile society and the offender. Nevertheless, the court pointed out the important caveat that these aims must be balanced against the interests of the community, including the interest in being protected against crime. ${ }^{130}$

\subsection{Dikoko v Mokhatla: delict and restorative justice}

Moving from criminal wrongdoing to civil wrongdoing, the picture changes somewhat. It appears that ubuntu has "been far less welcome in the field of private law than public law". ${ }^{131}$ Bennett notes that Dikoko $v$ Mokhatla ${ }^{132}$ is the only delict case so far in which ubuntu was considerably influential. Sachs and Mokgoro JJ were instrumental in bringing the restorative dimensions of ubuntu to bear on the law of delict.

The issue concerned whether or not statements made by municipal councillors in the course of carrying out their official functions are immune from liability in defamation,

Van Vuren v Minister of Correctional Services 20121 SACR 103 (CC).

In terms of section 136(1) of the Correctional Services Act 8 of 1959.

Van Vuren v Minister of Correctional Services 20121 SACR 103 (CC) para 51.

Van Vuren v Minister of Correctional Services 20121 SACR 103 (CC) para 51.

Bennett 2011 PEL 40.

Dikoko v Mokhatla 2006 SA 235 (CC). 
and if a public hearing of the Council is protected by privilege. ${ }^{133}$ The Court unanimously upheld the High Court's finding that the statements were not afforded privilege by statute or the Constitution. Mokgoro and Sachs JJ both invoked ubuntu in deciding that the order of damages imposed by the High Court was inappropriate. Mokgoro J would have reduced the amount ${ }^{134}$ while Sachs J would have replaced it with an order requiring an apology. ${ }^{135}$

According to Mokgoro J, the basic constitutional value of human dignity "relates closely" to ubuntu, and is based on a "deep respect for the humanity of another". ${ }^{136}$ She noted that traditionally African law and culture aim principally to restore harmony to fractured relationships and that, in the context of cases of compensation for defamation, the goal of our law should not be simply to "enlarge the hole in the defendant's pocket". ${ }^{137}$ She explained that compensatory damages are intended to restore the insulted dignity of the plaintiff, rather than to punish the defendant. This is better achieved, she said, through restorative than through retributive justice. The courts: ${ }^{138}$

should attempt, wherever feasible, to re-establish a dignified and respectful relationship between the parties. Because an apology serves to recognise the human dignity of the plaintiff, thus acknowledging, in the true sense of ubuntu, his or her inner humanity, the resultant harmony would serve the good of both the plaintiff and the defendant.

In Sachs J's view, the post-apartheid constitutional ethos demands a move away from a preoccupation with monetary awards in the law of defamation to a flexible and "broadly-based" approach that promotes the restoration of social harmony and "interpersonal repair". ${ }^{139}$ The injured party's reputation and dignity were harmed by the wrongdoer's "silly and self-serving words". He was entitled thus to see the wrongdoer chastised publically, to have his integrity affirmed, and to have the slur withdrawn; in other words, an apology was deserved. Monetary awards were

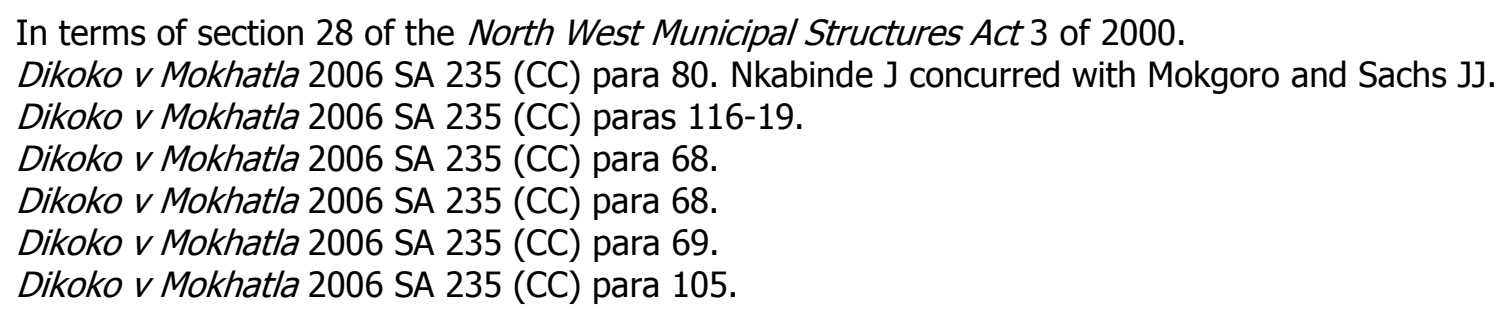


inappropriate because dignity, reputation and honour are not "market-place commodities". The "true and lasting solace" for a plaintiff successful in a defamation case results from the Court's affirmation of his dignity and reputation. ${ }^{140}$ Drawing on ubuntu principles, Sachs J argued that "the reparative value of retraction and apology" should be given a more prominent role. ${ }^{141}$ He reaffirmed the important constitutional status of ubuntu, clarifying that it: ${ }^{142}$

has an enduring and creative character, representing the element of human solidarity that binds together liberty and equality to create an affirmative and mutually supportive triad of central constitutional values. It feeds pervasively into and enriches the fundamental rights enshrined in the Constitution.

Defamation cases are especially amenable to affirming the values of ubuntu; consequently, remedies using apology should be explored. The Justices pointed out the consonance between their ubunturinspired reasoning in this case and the Roman-Dutch remedy of amende honorable. This remedy involves a retraction of the offending speech and an apology by the defendant. ${ }^{143}$ It shares the same underlying goal and philosophy as ubuntu. ${ }^{144}$ Furthermore, the principles of ubuntu echo the increasing and evolving global efforts to develop restorative systems of justice. ${ }^{145}$

Almost five years later, in The Citizen 1978 (Pty) Ltd $v$ McBride, ${ }^{146}$ ubuntu reappeared before the Constitutional Court in another defamation matter. The respondent had been granted amnesty in 1997 in terms of the Promotion of National Unity and Reconciliation Act. ${ }^{147} \mathrm{He}$ had been convicted of murder (and sentenced to death) for atrocities committed while an ANC operative. The issue was whether a newspaper was liable for defamation for publishing articles that called the respondent a "murderer", claimed that he lacked contrition for his crimes, and implicated him in criminal activities with gun dealers in Mozambique. These events

\footnotetext{
140 Dikoko v Mokhatla 2006 SA 235 (CC) para 109.

141 Dikoko v Mokhatla 2006 SA 235 (CC) para 112.

142 Dikoko v Mokhatla 2006 SA 235 (CC) para 113.

143 Dikoko v Mokhatla 2006 SA 235 (CC) para 63, where Mokgoro J cited Willis J's explanation of the remedy in Mineworkers Investment Co (Pty) Ltd v Modibane 20026 SA 512 (CC).

144 Dikoko v Mokhatla 2006 SA 235 (CC) para 116.

145 Dikoko v Mokhatla 2006 SA 235 (CC) para 114.

146 The Citizen 1978 (Pty) Ltd v McBride 20114 SA 191 (CC).

147 Promotion of National Unity and Reconciliation Act 34 of 1995.
} 
took place after amnesty, when the respondent was a candidate for a senior police post. The majority opinion was that, aside from the claim of a lack of contrition (which was indeed defamatory), none of the other allegations of defamation could succeed. ${ }^{148}$

The minority opinion was that the right to dignity was infringed by the malicious statements which were "calculated to expose [him] to odium, ill will and disgrace". ${ }^{149}$ Several remarks about the importance of ubuntu to both traditional African society as well as to the interpretation of the Constitution followed: ${ }^{150}$

Botho or ubuntu is the embodiment of a set of values and moral principles which informed the peaceful co-existence of the African people in this country who espoused ubuntu based on, among other things, mutual respect.

South Africa was being "rapidly denuded" of these values and moral standards; "a new culture has taken root". Reminiscent of Khumalo J in Bophuthatswana Broadcasting Corporation, ${ }^{151}$ Mogoeng J stated further that ubuntu gives expression to the "biblical injunction" that a man should do unto others as he would have them do unto him. In addition to the foundational value of human dignity, our "rich values, like Ubuntu" need to "colour the spectacles" through which we view claims of defamation. Finally, ${ }^{152}$

In cases of defamation that relate to the amnesty process sensitivity to this national project is called for. The law cannot simply be applied with little regard to the truth and reconciliation process and ubuntu.

Clearly, in the view of Mogoeng J, greater sensitivity to these issues might have changed the view of the majority.

The Citizen 1978 (Pty) Ltd v McBride 20114 SA 191 (CC) para 136.

The Citizen 1978 (Pty) Ltd v McBride 20114 SA 191 (CC para 239.

The Citizen 1978 (Pty) Ltd v McBride 20114 SA 191 (CC) para 217.

Bophuthatswana Broadcasting Corporation v Ramosa $1997 \mathrm{HOL} 283$ (B).

The Citizen 1978 (Pty) Ltd v McBride 20114 SA 191 (CC) para 243. 


\subsection{Eviction cases following PE Municipality}

A detailed account of the legal role of ubuntu is evident in City of Johannesburg $v$ Rand Properties (Pty) $L t d .{ }^{153}$ An inner city renewal project sought to clear buildings that presented significant health and safety risks to the occupants. It was common cause that the City did not intend to provide alternative accommodation for the occupants, who were mostly extremely poor. The central issue was whether the City was empowered to order people to vacate unsafe buildings ${ }^{154}$ without providing adequate alternative accommodation.

Jajbhay $\mathrm{J}$ considered the issue in the light of the right to access adequate housing, both as a fundamental human right and as guaranteed by section 26(1) of the Constitution: ${ }^{155}$

The fundamental point is that the Applicant may not exercise its powers and perform its functions and duties in relation to health and safety in a manner which violates the Respondents' constitutionally guaranteed rights - in particular the right of access to housing, protection against arbitrary eviction and the right to dignity.

In this case, eviction would have caused homelessness, and "a vicious circle, to the deprivation of their employment, their livelihood, and therefore their right to dignity, perhaps even their right to life". ${ }^{156}$ Citing PE Municipality, Jajbhay J affirmed that the courts need to "weave the elements of humanity and compassion within the fabric of the formal structures of the law". ${ }^{157}$ Drawing on Makwanyane, Jajbhay J went on to say that: $:^{158}$

153 City of Johannesburg $v$ Rand Properties (Pty) Ltd 20071 SA 78 (W).

154 Under the National Building Regulations and Building Standards Act 103 of $1977^{154}$ and the Health Act 63 of 1977,154

155 City of Johannesburg $v$ Rand Properties (Pty) Ltd 20071 SA 78 (W) para 59. It is worth noting that when this case went on appeal, the SCA found Jajbhay J's ruling wanting in several respects, describing its reasoning as "not always easy to follow", and holding it had conflated different issues. See City of Johannesburg v Rand Properties (Pty) Ltd 20076 SA 417 (SCA) para 32.

156 City of Johannesburg v Rand Properties (Pty) Ltd 20071 SA 78 (W) para 64.

157 City of Johannesburg v Rand Properties (Pty) Ltd 20071 SA 78 (W) para 62.

158 City of Johannesburg $v$ Rand Properties (Pty) Ltd 20071 SA 78 (W) para 63. 
[i]n South Africa the culture of ubuntu is the capacity to express compassion, justice, reciprocity, dignity, harmony and humanity in the interests of building, maintaining and strengthening the community. Ubuntu speaks to our interconnectedness, our common humanity and the responsibility to each that flows from our connection.

Urbanisation, wealth-accumulation and materialism ought not to be allowed to "rob us of our warmth, hospitality and genuine interests in each other as human beings". Ubuntu recognises the status of each person as deserving of unconditional respect, dignity, value and acceptance from the community of which one is a member. Jajbhay $\mathrm{J}$ regarded the suggestion that the occupants be relocated to an informal settlement as one that "flies in the face of the concept that 'a person is a person through persons'", as embodied by ubuntu. ${ }^{159}$ He emphasised that the right to work is one of the most valuable rights of all - "to work", he stated, "means to eat and consequently to live". Given his belief that "ubuntu must become a notion with particular resonance in the building of our constitutional democracy", Jajbhay J held that the City was required to enable the occupants to have access to adequate housing in the inner city. ${ }^{160}$

The strongly aspirational and idealistic tone adopted by Jajbhay $\mathrm{J}$ is clearly evident in this matter. As the case progressed through the higher courts, some of these points were countered by those courts: eg, while the interest in being able to work is not disputed, the demand for alternative accommodation in the inner city when there was no realistic likelihood of the city being able to supply it was rejected. The pace of urbanisation and the difficulties experienced with meeting the increasingly high demand for housing meant that informal settlements were an inevitable part of the peri-urban landscape. Furthermore, a city could operate only within its available

159 City of Johannesburg $v$ Rand Properties (Pty) Ltd 20071 SA 78 (W) para 64.

160 City of Johannesburg $v$ Rand Properties (Pty) Ltd 20071 SA 78 (W) para 67. It is worth mentioning that Jajbhay J made similar comments in Tshabalala-Msimang v Makhanya 20086 SA 102 (W) where he stated (para 1) that "[i]n South Africa we have a value system based on the culture of ubuntu. This in effect is the capacity to express compassion, justice, reciprocity, dignity, harmony and humanity in the interests of building, maintaining and strengthening the community. Ubuntu speaks to our inter-connectedness, our common humanity and the responsibility to each that flows from our connection. Ubuntu is a culture which places some emphasis on the commonality and on the interdependence of the members of the community. It recognises a person's status as a human being, entitled to unconditional respect, dignity, value and acceptance from the members of the community that such a person may be part of. In South Africa ubuntu must become a notion with particular resonance in the building of our constitutional democracy." 
resources. Consequently, provided it had a reasonable housing programme and catered also for emergency and dire need situations, a court could not order it to provide what it did not have.

In City of Johannesburg Metropolitan Municipality v Blue Moonlight Properties ${ }^{161}$ the Constitutional Court reaffirmed the relevance of ubuntu for interpreting PIE and its status as "underlying the Constitution" generally.

\subsection{Afri-forum v Malema: a final restorative justice case}

Whether or not the publication of pejorative words (shoot the Boer) in a "struggle" song constitutes hate speech in post-apartheid South Africa arose for consideration in Afri-forum v Malema. ${ }^{162}$ The Equality Court found that the intention behind such publication or communication ${ }^{163}$

could reasonably be construed to demonstrate an intention to be hurtful, to incite harm and promote hatred against the white Afrikaans-speaking community, including the farmers who belong to that group

in contravention of section 10 of the Promotion of Equality and Prevention of Unfair Discrimination Act. ${ }^{164}$ The court relied significantly on the principles of ubuntu, identifying twelve in total: ${ }^{165}$

An ubuntu-based jurisprudence has been developed particularly by the Constitutional Court. Ubuntu is recognised as being an important source of law within the context of strained or broken relationships amongst individuals or communities and as an aid for providing remedies which contribute towards more mutually acceptable remedies for the parties in such cases. Ubuntu is a concept which

1. is to be contrasted with vengeance;

2. dictates that a high value be placed on the life of a human being;

161 City of Johannesburg Metropolitan Municipality v Blue Moonlight Properties 39 (Pty) Ltd 20122 SA 104 (CC) para 38.

162 Afri-Forum v Malema 20116 SA 240 (EqC).

163 Afri-Forum v Malema 20116 SA 240 (EqC) para 108.

164 Section 10 of the Promotion of Equality and Prevention of Unfair Discrimination Act 4 of 2000.

165 Afri-Forum v Malema 20116 SA 240 (EqC) para 18. 
3. is inextricably linked to the values of and which places a high premium on dignity, compassion, humaneness and respect for humanity of another;

4. dictates a shift from confrontation to mediation and conciliation;

5. dictates good attitudes and shared concern;

6. favours the re-establishment of harmony in the relationship between parties and that such harmony should restore the dignity of the plaintiff without ruining the defendant;

7. favours restorative rather than retributive justice;

8. operates in a direction favouring reconciliation rather than estrangement of disputants;

9. works towards sensitising a disputant or a defendant in litigation to the hurtful impact of his actions to the other party and towards changing such conduct rather than merely punishing the disputant;

10. promotes mutual understanding rather than punishment;

11. favours face-to-face encounters of disputants with a view to facilitating differences being resolved rather than conflict and victory for the most powerful; and

12. favours civility and civilised dialogue premised on mutual tolerance.

The majority of these characteristics relate to restorative justice, which, as is by now clear, is closely linked to ubuntu. The characteristics listed reflect the description of ubuntu in the interim Constitution. They are also classical tools of restorative justice. In addition, the link between ubuntu and the value of life, dignity, compassion, humaneness, respect for humanity and shared concern is also evident, as was reflected in Makwanyane, PE Municipality and Dikoko, to name but a few cases.

The Equality Court found that, when words or phrases have different meanings for different people, each meaning must be considered and accepted as relevant in the context of a hate speech claim. The focus is on what the target group reasonably would be likely to attribute to the words, rather than on the meaning claimed by the speaker. ${ }^{166}$ These particular words sung on several occasions by Malema, concerned an easily recognisable (if not precisely identifiable) group, namely white Afrikaners, especially from rural areas. The words undermined that group's dignity and were unfairly discriminatory and harmful in post-apartheid South Africa. It must never be forgotten that in the spirit of ubuntu this new approach to one another must be fostered. ${ }^{167}$

\footnotetext{
166 Afri-Forum v Malema 20116 SA 240 (EqC) para 109.

167 Afri-Forum v Malema 20116 SA 240 (EqC) para 108.
} 


\subsection{Reflection}

PE Municipality, we can now see, paved the way for courts to apply ubuntu principles in cases that call for a restorative justice approach. It is worth noting that this requires a specific type of application of the principles of ubuntu. Although it is always closely tied to notions of rehabilitation and reconciliation, we know that ubuntu has much broader import as well. Ubuntu can be applied to emphasise communal values or to appeal to values such as compassion, empathy or interdependence without the restorative justice context. Restorative justice is relevant to a conflict situation - eg between a criminal and the community, an evictor and evictees, and so on - that might be ameliorated or even resolved through mediation, apology, dialogue and other restorative measures. Our point here is that restorative justice is undoubtedly one of the facets of $u b u n t u$, but by definition the existence of other facets thereof is implied. That said, as has been illustrated, a great variety of situations lend themselves to restorative justice and we can thus expect invocation of ubuntu in the name of restorative justice to remain fertile ground for this burgeoning area of the law.

The next section examines some of the other facets of ubuntu as illustrated by a miscellany of cases post-PE Municipality.

\section{The "rainbow effect" of ubuntu}

Most of the cases discussed in this section seem to use ubuntu without discussing its nature in any detail. Still, the expansion of the principles of ubuntu to areas of law outside of restorative justice merits examination. The extensive variety of contexts illustrates the potential pervasiveness of these principles in the pursuit of justice as well as dignity, freedom and equality. In what follow we briefly examine Bhe $v$ Magistrate, Khayelitsha, ${ }^{168}$ New Clicks South Africa (Pty) Ltd v Tshabalala-Msimang,

168 Bhe v Magistrate, Khayelitsha; Shibi v Sithole; South African Human Rights Commission v President of the Republic of South Africa 20051 SA 580 (CC). 
Pharmaceutical Society of South Africa v Minister of Health, ${ }^{169}$ Union of Refugee Women v Director: Private Security Industry Regulatory Authority, ${ }^{170}$ Barkhuizen v Napier, ${ }^{171}$ Maset/ha $v$ President of the Republic of South Africa, ${ }^{172}$ Koyabe $v$ Minister for Home Affairs, ${ }^{173}$ and Everfresh Market Virginia (Pty) Ltd $v$ Shoprite Checkers (Pty) $L t d^{174}$

\subsection{Customary law}

In ruling that the rule of male primogeniture ${ }^{175}$ was unconstitutional, Langa $D C J^{176}$ in Bhe $v$ Magistrate, Khayelitsha ${ }^{177}$ referred to ubuntu whilst elaborating on "positive aspects of customary law", which in South African law had been "long neglected". In addition to flexibility, customary law places great emphasis on consensus-seeking and provides ample opportunity for both the prevention and the resolution of conflicts. More broadly, these aspects of customary law ${ }^{178}$

provide a setting which contributes to the unity of family structures and the fostering of co-operation, a sense of responsibility in and of belonging to its members, as well as the nurturing of healthy communitarian traditions such as ubuntu.

Ngcobo J explained that ubuntu, a "dominant value in traditional African culture", manifests the strong sense of community that arises out of "an elaborate system of reciprocal duties and obligations" amongst family members. ${ }^{179}$ The assumption of a

\footnotetext{
169 New Clicks South Africa (Pty) Ltd v Tshabalala-Msimang; Pharmaceutical Society of South Africa $v$ Minister of Health 20053 SA 231 (C).

170 Union of Refugee Women v Director: Private Security Industry Regulatory Authority 20074 SA 395 (CC).

171 Barkhuizen v Napier 20075 SA 323 (CC).

172 Maset/ha $v$ President of the Republic of South Africa 20081 SA 566 (CC).

173 Koyabe $v$ Minister for Home Affairs 20104 SA 327 (CC).

174 Everfresh Market Virginia (Pty) Ltd v Shoprite Checkers (Pty) Ltd 20121 SA 256 (CC).

175 And also relevant legislative provisions that supported male primogeniture, including s 23 of the Black Administration Act 38 of 1927.

176 As he then was.

177 Bhe v Magistrate, Khayelitsha; Shibi v Sithole; South African Human Rights Commission v President of the Republic of South Africa 20051 SA 580 (CC) para 45.

178 Bhe v Magistrate, Khayelitsha; Shibi v Sithole; South African Human Rights Commission v President of the Republic of South Africa 20051 SA 580 (CC) para 45.

179 Bhe v Magistrate, Khayelitsha; Shibi v Sithole; South African Human Rights Commission v President of the Republic of South Africa 20051 SA 580 (CC) para 163.
} 
close link between kinship and community is fundamental to this understanding of ubuntu in a traditional African context. However, it does not seem plausible that ubuntu can be properly understood only if kinship is part of the context. In general terms, South Africans appear to feel connected even when they know they are not directly related in biological terms. This is particularly evident amongst expatriates abroad who unexpectedly find themselves hearing a familiar accent or slang usage. The joy of recognition is indicative of this connection. Bhe also illustrates clearly the respect for individuals that ubuntu requires. This facet is not always recognised by those who think ubuntu is only about the collective.

\subsection{Respect for persons}

In New Clicks South Africa (Pty) Ltd v Tshabalala-Msimang; Pharmaceutical Society of South Africa $v$ Minister of Health, ${ }^{180}$ the validity of regulations made by the Minister of Health, designed to give effect to a new pricing system for the sale of medicines as envisaged by amendments to the Medicines and Related Substances $A c t_{,}^{181}$ was challenged. The High Court dismissed the challenge, whereupon the applicants sought leave to appeal. Infamously, the High Court delayed its judgment for several months, leading to the applicants applying directly to the Supreme Court of Appeal (SCA) for leave to appeal. In these almost unprecedented circumstances, the High Court finally delivered its judgment just before that of the SCA. Consonant with the tensions prevailing, the two judgments were contradictory: the High Court dismissed the application (2:1) but the $\mathrm{SCA}^{182}$ granted it unanimously.

In support of the dismissal of the application for leave to appeal, the High Court reiterated that a value underpinning a society based on dignity, freedom and equality is ubuntu and, quoting Mfuniselwa Bhengu, ${ }^{183}$ it held that "[u]buntu is 'a way of life that contributes positively towards sustaining the well-being of a people,

180 New Clicks South Africa (Pty) Ltd v Tshabalala-Msimang; Pharmaceutical Society of South Africa $v$ Minister of Health 20053 SA 231 (C).

181 Medicines and Related Substances Act 101 of 1965.

182 Pharmaceutical Society of South Africa v Tshabalala-Msimang; New Clicks South Africa (Pty) Ltd $v$ Minister of Health 20053 SA 238 (SCA).

183 Bhengu Ubuntu: Essence of Democracy. 
community or society"'. ${ }^{184}$ Consequently, "ubuntu requires that medicine must be accessible to all South Africans, rich and poor". ${ }^{185}$ This bolstered the view that the regulations were aimed at achieving this goal as well as the subsequent decision to dismiss the application for leave to appeal.

The SCA ${ }^{186}$ granted leave to appeal and, having heard the merits of the case as well, found in favour of the appellants, holding the regulations to be invalid. Writing for a unanimous court, Harms JA stated that "[u]buntu has many applications" and it ${ }^{187}$

ought to apply to the relationship between courts and the respect required of State and courts towards citizens and towards each other.

This remark followed the finding that the High Court's long delay in delivering judgment, including the lack of an explanation for the delay in the light of the urgency of the case, was so unreasonable and "regrettable" as to constitute a refusal of leave. Clearly the intention was to indicate that the delay in delivering judgment fell far short of the standards imposed on the judiciary by the constitutional norm of ubuntu. Again, in New Clicks, respect was the focus of attention, at least in the SCA: respect for each other as people; respect for the infrastructure that facilitates the pursuit of justice, including professionalism and the observance of duty.

The lawfulness of administrative action by the Private Security Industry Regulatory Authority ("the Authority") in respect of refugees from other African countries was under scrutiny in Union of Refugee Women v Director: Private Security Industry Regulatory Authority. ${ }^{188}$ Foreigners' registration to practise as security service providers in South Africa was withdrawn on the basis that they were not South

184 New Clicks South Africa (Pty) Ltd v Tshabalala-Msimang; Pharmaceutical Society of South Africa $v$ Minister of Health 20053 SA 231 (C) 237G.

185 New Clicks South Africa (Pty) Ltd v Tshabalala-Msimang; Pharmaceutical Society of South Africa $v$ Minister of Health 20053 SA 231 (C) 237G.

186 Pharmaceutical Society of South Africa v Tshabalala-Msimang; New Clicks South Africa (Pty) Ltd $v$ Minister of Health 20053 SA 238 (SCA).

187 Pharmaceutical Society of South Africa v Tshabalala-Msimang; New Clicks South Africa (Pty) Ltd $v$ Minister of Health 20053 SA 238 (SCA) para 39.

188 Union of Refugee Women v Director: Private Security Industry Regulatory Authority 20074 SA 395 (CC). 
African citizens or permanent residents of the Republic. ${ }^{189}$ Persons without citizenship or permanent resident status were barred from registration, subject to an exemption clause, ${ }^{190}$ which provided a wide discretion when "good cause" was shown. ${ }^{191}$

The Constitutional Court held that the Authority's conduct fell short of the standards of procedurally fair administrative action demanded by the Promotion of Administrative Justice Act ("PAJA") ${ }^{192}$ as well as the Constitution. ${ }^{193}$ The Authority should of its own accord have informed the applicants of the possibility of an exemption, which it failed to do. ${ }^{194}$ Sachs J emphasised the legal obligations owed to refugees in South Africa and the considerations that needed to be taken into account in determining refugees' access to various employment industries. Though refugee status does not entitle someone to be admitted "as of right" to all spheres of the private security industry, ${ }^{195}$ international and domestic law enjoins officials to: ${ }^{196}$

strongly favour acknowledging the right of refugees to seek employment in all spheres of economic activity.

Sachs J referred approvingly to the statements in PE Municipality about how ubuntu suffuses South Africa's constitutional democracy and that people in the Republic are not islands unto themselves. Although the statements were made in the context of eviction, the sentiments ought to apply with equal vigour "to our relationship with the rest of the continent". ${ }^{197}$ This was in line with "the concept of human interdependence and burden-sharing in relation to catastrophe", which "is associated with the spirit of ubuntu-botho". ${ }^{198}$

\footnotetext{
189 In terms of s 23(1) of the Private Security Industry Regulation Act 56 of 2001.

190 Section 23(6) of the Private Security Industry Regulation Act 56 of 2001.

191 Section 23(6) of the Private Security Industry Regulation Act 56 of 2001.

192 Section 3 of the Promotion of Administrative Justice Act 3 of 2000.

193 Section 195(1)(g) of the Constitution of the Republic of South Africa Act 200 of 1993.

194 Union of Refugee Women v Director: Private Security Industry Regulatory Authority 20074 SA 395 (CC) para 83.

195 Union of Refugee Women v Director: Private Security Industry Regulatory Authority 20074 SA 395 (CC) para 149.

196 Union of Refugee Women v Director: Private Security Industry Regulatory Authority 20074 SA 395 (CC) para 127.

197 Union of Refugee Women v Director: Private Security Industry Regulatory Authority 20074 SA 395 (CC) para 145.

198 Union of Refugee Women v Director: Private Security Industry Regulatory Authority 20074 SA 395 (CC) para 145.
} 
Although, technically, the subject matter was administrative action, the effect of introducing ubuntu into the matter was to highlight the absence of respect for the refugees by the authority. This shows yet again why respect is fundamental to building a society based on dignity, freedom and equality.

In a similar vein, in Koyabe $v$ Minister for Home Affairs ${ }^{199}$ the Constitutional Court determined whether or not certain constitutional and statutory rights of the applicants - all Kenyan nationals - had been violated by administrative action taken by the Department of Home Affairs. A unanimous court asserted that, having been declared illegal foreigners, the applicants were entitled to reasons for this decision: ${ }^{200}$

In the context of a contemporary democratic public service like ours, where the principles of Batho Pele, coupled with the values of ubuntu, enjoin the public service to treat people with respect and dignity and avoid undue confrontation, the Constitution indeed entitles the applicants to reasons for the decision declaring them illegal foreigners. It is excessively over-formalistic and contrary to the spirit of the Constitution for the respondents to contend that under section 8(1) they were not obliged to provide the applicants with reasons.

That the State, whether directly or indirectly through its delegated entity, should regard people who have the misfortune to be refugees, whether political or economic, as not meriting respectful treatment was thought to be shameful. Were it not able to call on the principles of ubuntu, one wonders how the Court would have substantiated its position. Quite clearly, in our view this situation indicates clearly the importance of the African concept to the business of persuading all South Africans, including the State, that respect is not negotiable when dealing with persons.

The practice of the short-term insurance industry of imposing time limitation clauses in policies has to meet standards of reasonableness and fairness or risk being

199 Koyabe v Minister for Home Affairs 20104 SA 327 (CC).
200 Koyabe v Minister for Home Affairs 20104 SA 327 (CC) para 62. 
contrary to public policy. This was the finding in Barkhuizen $v$ Napier. ${ }^{201}$ The Constitutional Court affirmed that: ${ }^{202}$

Broadly speaking the test announced in Mohlomi is whether a provision affords a claimant an adequate and fair opportunity to seek judicial redress. Notions of fairness, justice and equity, and reasonableness cannot be separated from public policy. Public policy takes into account the necessity to do simple justice between individuals. Public policy is informed by the concept of ubuntu. It would be contrary to public policy to enforce a time-limitation clause that does not afford the person bound by it an adequate and fair opportunity to seek judicial redress.

The statement that public policy is informed by ubuntu seems almost trite by now. In a relatively short time frame, the Constitutional Court has been able to remind us repeatedly of just how all-pervasive the fundamentals of ubuntu are to the interpretation of the Bill of Rights.

In Masettha $v$ President of the Republic of South Africa ${ }^{203}$ the Constitutional Court reflected on the constitutionality of a presidential decision to suspend the DirectorGeneral of the National Intelligence Agency by the unilateral amendment of his terms of employment. This permitted Sachs J occasion to consider the connection between fair dealing and civility, which he held cannot be separated. ${ }^{204}$ Civility is one of the "binding elements" of a constitutional democracy, involving tolerance, even in the face of disagreement, as well as respect for dignity: 205

Civility, closely linked to ubuntu-botho, is deeply rooted in traditional culture, and has been widely supported as a precondition for the good functioning of contemporary democratic societies.

Furthermore, such tolerance and respect oblige even the President to behave in accordance with the principles of ubuntu, notwithstanding the stature and authority of the position of President.

Barkhuizen v Napier 20075 SA 323 (CC).

Barkhuizen v Napier 20075 SA 323 (CC) para 51 (our emphasis).

Maset/ha $v$ President of the Republic of South Africa 20081 SA 566 (CC).

Maset/ha v President of the Republic of South Africa 20081 SA 566 (CC) para 238.

Maset/ha v President of the Republic of South Africa 20081 SA 566 (CC) para 238. 


\subsection{Ubuntu and contract law}

Finally, in Everfresh Market Virginia (Pty) Ltd v Shoprite Checkers (Pty) $L t d,{ }^{206}$ the Constitutional Court reflected on when it should intervene to develop contract law in the light of the spirit, purport and objects of the Bill of Rights, as required by section 39(2) of the Constitution. The reader will recall the earlier remark about the reluctance of Private Law to consider itself in the light of the Constitution. ${ }^{207}$ In this case, whether contract law should require good faith negotiations rather than permit reneging for commercial reasons was under consideration. An option to renew a lease was found to be invalid on technical grounds. The Court differed in its view of the substantive claim: the majority refused leave to appeal to the Court but accepted the argument that the concept of ubuntu has "been recognised as informing public policy in a contractual context"208 - undoubtedly a reference to Barkhuizen $v$ Napier. The role of ubuntu in shaping the development of the common law - including contract law - was accepted: ${ }^{209}$

Had the case been properly pleaded, a number of inter-linking constitutional values would inform a development of the common law. Indeed, it is highly desirable and in fact necessary to infuse the law of contract with constitutional values, including values of ubuntu, which inspire much of our constitutional compact....Were a court to entertain Everfresh's argument, the underlying notion of good faith in contract law, the maxim of contractual doctrine that agreements seriously entered into should be enforced, and the value of ubuntu, which inspires much of our constitutional compact, may tilt the argument in its favour. Contracting parties certainly need to relate to each other in good faith.

The minority opinion meanwhile stated that contract law could no longer confine itself to colonial legal traditions, which shaped and developed the common law before the advent of post-apartheid democracy. In its view, the notion that people could back-pedal from undertakings to negotiate for commercial reasons "certainly implicates ubuntu". ${ }^{210}$

Everfresh Market Virginia (Pty) Ltd v Shoprite Checkers (Pty) Ltd 20121 SA 256 (CC).

Bennett 2011 PELJ 40.

Everfresh Market Virginia (Pty) Ltd v Shoprite Checkers (Pty) Ltd 20121 SA 256 (CC) para 61.

Everfresh Market Virginia (Pty) Ltd v Shoprite Checkers (Pty) Ltd 20121 SA 256 (CC) paras 71 and 72.

210 Everfresh Market Virginia (Pty) Ltd v Shoprite Checkers (Pty) Ltd 20121 SA 256 (CC) para 24. 


\section{$7 \quad$ Reflections}

In this section, we consider a few broader critical and analytical aspects of ubuntu in our developing jurisprudence. Some of the reflections flow from comments raised by critics elsewhere.

\subsection{Potential for conflict between ubuntu and the Bill of Rights}

It seems fair to ask if the values of ubuntu may conflict with those of the Bill of Rights, notwithstanding the claims of several Constitutional Court Justices that ubuntu serves to support and underpin the Bill of Rights and to assist with the latter's interpretation. Ubuntu is a living system of values and, arguably, if there is consistency with the normative value system of the Bill of Rights, this may be a happy coincidence rather than an inevitable outcome. Nevertheless, the idea that ubuntu is entirely compatible with the Bill of Rights is repeatedly stated without explanation or supporting evidence. We wonder if this idea should be so easily accepted as an unquestioned assumption.

Repeatedly we return to the apparent lack of precision with which ubuntu has been invoked. It must be observed, however, that to date, the courts have applied ubuntu in a fairly uncontroversial manner. But we are aware that the value of group solidarity could clash with the value of fairness at the individual level; that conciliation might collide with communality, and so on. In these cases, what role might ubuntu play $?^{211}$ So far, the ubuntu-inspired post-apartheid jurisprudence gives little indication of whether or how, in hard cases, ubuntu might dictate case outcomes differently from what might be the case if it were unavailable as a legal concept.

211 See English 1996 SAJHR 648. 


\subsection{Communalism versus liberal individualism: a false dichotomy?}

Several references have been made to the communal characteristic of ubuntu, which is frequently contrasted with "liberal individualism". Kroeze is critical of the Constitutional Court's evocation of a strict dichotomy along these lines: ${ }^{212}$

[I]f liberalism is individualistic, ubuntu must be communitarian; if liberalism emphasises individual rights, ubuntu must stress group rights; competition $v$ compassion; confrontation v conciliation; and so on.

No particular judgment of the Court is identified to illustrate this point. Nevertheless, this alleged dichotomy between liberal individualism and communalism ${ }^{213}$ does sometimes present itself in the literature. For example, the reader will recall Bennett's remark that whereas the notion of dignity envisages the individual as the bearer of rights, ubuntu "sees the individual as embedded in a community". ${ }^{214}$

Kroeze believes that a classic demand of "traditional legal thinking" is for a choice to be made between (individualistic) liberalism and (ubuntu-based) communitarianism. Such a choice is simplistic, however, as it is unclear that liberalism and communitarianism necessarily conflict, and there may also be other possible choices. ${ }^{215}$ In similar vein, Marx questions the dichotomy frequently drawn between "Western individualism" and "African communitarianism", the latter being driven by ubuntu. ${ }^{216}$ The questions asked by Kroeze and Marx seem valid. In the absence of clear answers, it behoves us at least to be wary of assumptions about a clash between ubuntu and liberalism and about whether ubuntu has to be distinctively different in order to be valuable for constitutional interpretation.

Kroeze 2002 Stell LR261.

We prefer communal, communality, or communalism to communitarianism, the latter being a philosophical critique rather than a descriptor.

214 Bennett 2011 PELJ 48 (our emphasis).

215 Kroeze 2002 Stell $L R$ 261. The automatic equation of liberalism with individualism is also problematic.

216 Marx 2002 Politikon 61. 
Academic literature includes robust efforts to flesh out the precise sort of communalism that ubuntu might justifiably reflect. In endorsing the equation of ubuntu with "moderate communalism" Himonga ${ }^{217}$ draws from Kwame Gyekye: ${ }^{218}$

[In] a communitarian society rights may not be asserted or insisted on with belligerency, for communal values such as generosity, compassion, reciprocities, and the mutual sympathies may be considered to be more important than one's rights. Even so, this is far from saying that rights do not exist as part of the structure of a people's moral beliefs or values, or that rights are fictional or not at all essential in the communitarian moral and political theory and practice. ... $A$ communitarian denial of rights or reduction of rights to a secondary status does not adequately reflect the claims of individuality mandated in the notion of the moral worth of the individual.

Understanding ubuntu in terms of communalism that is inclusive of individual rights and autonomy ${ }^{219}$ allows the recognition of universal human rights in African cultural contexts without abandoning attributes of ubuntu like interdependence, dignity, solidarity and responsibility. ${ }^{220}$ These attempts seek to clarify and deepen our understanding of the relationship between a communal morality founded in ubuntu, on the one hand, and the legitimacy of universal individual rights, on the other. In our view, if ubuntu is to play a truly transformative role in South African jurisprudence, the courts must grapple with precisely these sorts of questions in their attempts to explain ubuntu substantively in different scenarios and thus to diminish the possibility of ambiguity.

\subsection{Does ubuntu encourage conformity with majority values?}

We now turn to the charge that post-apartheid South Africa's project of nationbuilding inevitably dictates a need for conformity and the suppression of dissidence. ${ }^{221}$ Marx believes that, regardless of the original meaning of ubuntu or its Christian theological appropriation by Desmond Tutu, ${ }^{222}$ it has been repackaged and

\footnotetext{
217 See Himonga "Exploring the Concept of Ubuntu" 9.

218 Gyekye Tradition and Modernity 62 (our emphasis).

219 Himonga "Exploring the Concept of Ubuntu" 8.

220 Himonga "Exploring the Concept of Ubuntu" 9.

221 Marx 2002 Politikon 53.

222 See Swartz 2006 Journal of Moral Education 560-561.
} 
"elevated into a central element of a new cultural nationalism"223 in the pursuit of harmonious nation-building and that the concept has become simultaneously both inclusive and exclusionary. ${ }^{224}$ Its inclusiveness, on this view, extends to those who accept the dictates of authorities. Dissidents, on the other hand, are excluded. After reflecting on Marx's position, Swartz sums up this concern eloquently: ${ }^{225}$

while ubuntu provides a basis for civic virtue, moral renewal and publicspiritedness, like so much else in the aftermath of apartheid, it conceals the need for redistributive justice and silences those who call attention to it - all in the name of public-spiritedness.

It is clear that ubuntu has been invoked by various different groups for different purposes and in different ways. However, no single group in society has a monopoly over the concept. One could engage in intricate historical debates about the extent to which these various constructed versions of ubuntu accurately correspond with ubuntu as a lived, traditional philosophy of life; however, this is not really our concern. Our interest is limited to how ubuntu has featured and might in future feature in South Africa's legal domain, particularly through constitutional interpretation.

Further criticism concerns the perception that ubuntu is linked with "public morality", in a manner which compromises Bill of Rights adjudication and, in particular, the rights of minorities. English argues that the definitions of ubuntu provided by Mokgoro, Mohamed and Sachs JJ in Makwanyane ${ }^{226}$ demonstrate a link between the concept of ubuntu and conformity to majority norms and standards. For example, she reflects on Mokgoro J's description of ubuntu as embodying the key values of "group solidarity", "conformity to basic norms" and "collective unity". 227 She quotes Kentridge AJ's extra-judicial definition of ubuntu as a "feeling of common humanity". ${ }^{228}$ She also notes Sachs J's statement that invoking ubuntu would "restore dignity to ideas and values that have long been suppressed or

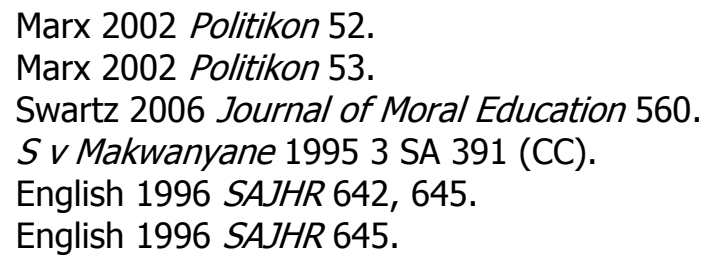


marginalised". In her view, these affirmations of ubuntu created a "contradiction" in Makwanyane, as the Court was equally keen to emphasise that the popular views of "the people at large" are not determinative of constitutional adjudication. ${ }^{229}$ For instance, Chaskalson $P$ pointed out clearly that: ${ }^{230}$

If public opinion were to be decisive, there would be no need for constitutional adjudication. The protection of rights could be left to Parliament, which has a mandate from the public, and is answerable to the public for the way its mandate is exercised, but this would be a return to parliamentary sovereignty, and a retreat from the new legal order established by the 1993 Constitution.

English clearly believes that ubuntu's apparent tie to majority morality might place a pressure on the judiciary to conform to popular norms, thereby undermining the interests of minorities. Her worry, voiced in 1996, may have been allayed somewhat by evidence to the contrary in the jurisprudence that has followed Makwanyane. Moreover, there is a difference between embracing the majority's adherence to ubuntu and sanctioning what the majority thinks on a particular issue. It has never been suggested by the Court that subscribing to ubuntu involves subscribing to a specific set of moral beliefs. For example, two people can agree that we need to abide by the principles of ubuntu and yet disagree as to whether ubuntu is compatible with the death penalty. Invoking ubuntu therefore need not sanction majority morality in the manner feared.

\section{Conclusion}

Many of the critiques outlined above referred to Makwanyane prior to later judgments that have also considered ubuntu as a legal concept. A particular concern seemed to be how ubuntu would illuminate the always thorny problem revealed when individual interests collide with public interests.

It is unclear why this should be a concern linked particularly to the principles of ubuntu. The tension between individual and public interests is always present.

229 English 1996 SAJHR 647.
230 S v Makwanyane 19953 SA 391 (CC) para 88. 
Whether one uses the principles of ubuntu or other so-called Western values to assess the balance and to find the appropriate outcome does not seem to be important. Might it be that the ubuntu principles are still not well-understood and thus engender fear-based suspicion that the concept will be used to get rid of the baby and the bathwater? In our view, this suspicion is unfounded. The discussion and analysis presented here shows the valuable contribution that the use of ubuntu principles has made to South African jurisprudence.

It should be apparent that ubuntu can be applied to virtually any area of law. The concept is sufficiently broad to have far-reaching application. Moreover, the status of ubuntu as a "golden thread" and "shared value running across cultural lines"231 in South African society has allowed judges to feel at ease to freely apply ubuntu to new areas of law. As a concept said to permeate the entire constitutional order, we can certainly expect its steadily increasing range of application to continue.

In tracing the evolution of ubuntu in South African courts since 1993 with emphasis on the historical and thematic development of the concept, we have attempted to show its content through the eyes of the courts and the manner in which it has been implemented. This article has shown two major epochs in the development of ubuntu, marked by the constitutional decisions in Makwanyane and PE Municipality respectively. While the former carved the central avenue of development for ubuntu, the latter marked the start of the thematic development of the concept in the direction of restorative justice. Although PE Municipality itself did not mention the term "restorative justice", the decision represents the beginning of the Constitutional Court's emphasis on the close connection between the concepts of ubuntu and restorative justice.

We have also examined the criticisms against conceptualisation of ubuntu as a legal notion, ranging from its ambiguity to its redundancy, to perceptions of dichotomies, and issues of exclusion. While dismissing most criticisms, the paper has affirmed, to a limited extent, the criticism of the ambiguity of ubuntu, and acknowledged the

231 S v Makwanyane 19953 SA 391 (CC) para 306. 
need for discussion and debate focused on gaining a shared understanding of it. The paper also questioned the manner in which the courts have applied the legal concept of ubuntu uncritically, without reference to African sources to illustrate its meaning in different contexts, and without questioning its compatibility with the Bill of Rights.

In our view the true value and usefulness of ubuntu as a legal concept and moral guide will be revealed only when all of us grapple to gain insight into its multifaceted character and the polycentric effect that it has on implementation. 


\section{Bibliography}

Bennett 2011 PELJ

Bennett TW "Ubuntu: an African Equity" 2011 PELJ 14(4) 30-61

Bhengu Ubuntu

Bhengu M Ubuntu: the Essence of Democracy (Novalis Press Cape Town 1996)

Cornell and Muvangua Ubuntu and the Law

Cornell D and Muvangua N (eds) Ubuntu and the Law: African Ideals and Postapartheid Jurisprudence (Fordham University Press New York 2012)

English 1996 SAJHR

English R "Ubuntu: The Quest for an Indigenous Jurisprudence" 1996 SAJHR 641-648

Gallie 1956 Proceedings of the Aristotelian Society

Gallie WB "Essentially Contested Concepts" 19561 Proceedings of the Aristotelian Society 67-198

Gyekye Tradition and Modernity

Gyekye K Tradition and Modernity: Philosophical Reflections on the African Experience (Oxford University Press Oxford 1997)

Himonga "Exploring the Concept of Ubuntu"

Himonga C "Exploring the Concept of Ubuntu in the South African Legal System" in Kischel U et al (eds) Ideologie und Weltschauung im Recht (Mohr Siebeck Tübingen 2012) 1-22 
Himonga 2013 Journal of African Law

Himonga C "The Right to Health in an African Cultural Context: the Role of Ubuntu in the Realization of the Right to Health with Special Reference to South Africa" 2013 Journal of African Law 165-195

Keep and Midgley "Emerging Role of Ubuntu-botho"

Keep $\mathrm{H}$ and Midgley $\mathrm{R}$ "The Emerging Role of Ubuntu-botho in Developing a Consensual South African Legal Culture" in Bruinsma F and Nelken D (eds) Recht der Werkelijkheid (Reed Business BV Gravenhage 2007) 29-56

Klare 1998 SAJHR

Klare K "Legal Culture and Transformative Constitutionalism" 1998 SAJHR $146-188$

Kroeze 2002 Stell LR

Kroeze IJ "Doing Things with Values II: The Case of Ubuntu" 2002 Stell $L R$ 252-264

Marx 2002 Politikon

Marx C "Ubu and Ubuntu: on the Dialectics of Apartheid and Nation Building" 2002 Politikon 49-69

Mokgoro 1998 PEL

Mokgoro JY "Ubuntu and the Law in South Africa" 1998 PEL 1-11

Skelton 2010 SAPL

Skelton A "Face to Face: Sachs on Restorative Justice" 2010 SAPL 94-107

Swartz 2006 Journal of Moral Education

Swartz S "A Long Walk to Citizenship: Morality, Justice and Faith in the Aftermath of Apartheid" 2006 Journal of Moral Education 551-570 


\section{Register of case law}

Afri-Forum v Malema 20116 SA 240 (EqC)

Barkhuizen v Napier 20075 SA 323 (CC)

Bhe v Magistrate, Khayelitsha; Shibi v Sithole; South African Human Rights Commission v President of the Republic of South Africa 20051 SA 580 (CC)

Bophuthatswana Broadcasting Corporation v Ramosa 1997 HOL 283 (B)

Bührmann v Nkosi 19994 All SA 337 (T)

City of Johannesburg Metropolitan Municipality v Blue Moonlight Properties 39 (Pty) Ltd 20122 SA 104 (CC)

City of Johannesburg v Rand Properties (Pty) Ltd 20071 SA 78 (W)

City of Johannesburg $v$ Rand Properties (Pty) Ltd 20076 SA 417 (SCA)

Crossley v National Commissioner, SAPS 20043 All SA 436 (T)

Dikoko v Mokhatla 20066 SA 235 (CC)

Du Plooy v Minister of Correctional Services 20043 All SA 613 (T)

Everfresh Market Virginia (Pty) Ltd v Shoprite Checkers (Pty) Ltd 20121 SA 256 (CC) Investigating Directorate: Serious Economic Offences $v$ Hyundai Motor Distributors

(Pty) Ltd: In re Hyundai Motor Distributors (Pty) Ltd v Smit 20011 SA 545 (CC).

Koyabe v Minister for Home Affairs 20104 SA 327 (CC)

Maset/ha v President of the Republic of South Africa 20081 SA 566 (CC)

Mayelane v Ngwenyama 20134 SA 415 (CC).

MEC for Education: Kwazulu-Natal v Pillay 20081 SA 474 (CC)

Mineworkers Investment Co (Pty) Ltd v Modibane 20026 SA 512 (CC)

New Clicks South Africa (Pty) Ltd v Tshabalala-Msimang; Pharmaceutical Society of

South Africa v Minister of Health 20053 SA 231 (C)

Pharmaceutical Society of South Africa v Tshabalala-Msimang; New Clicks South

Africa (Pty) Ltd v Minister of Health 20053 SA 238 (SCA)

Port Elizabeth Municipality v Various Occupiers 20051 SA 217 (CC)

S v Makwanyane 19953 SA 391 (CC)

$S$ v Maluleke 20081 SACR 49 (T)

$S$ v Mandela 20011 SACR 156 (C) 
$S$ v Shilubane 20081 SACR 295 (T)

$S$ v Sibiya 20101 SACR 284 (GNP)

The Citizen 1978 (Pty) Ltd v McBride 20114 SA 191 (CC)

Tshabalala-Msimang v Makhanya 20086 SA 102 (W)

Union of Refugee Women v Director: Private Security Industry Regulatory Authority 20074 SA 395 (CC)

Van Vuren v Minister of Correctional Services 20121 SACR 103 (CC)

\section{Register of legislation}

Black Administration Act 38 of 1927

Constitution of the Republic of South Africa Act 200 of 1993

Constitution of the Republic of South Africa, 1996

Correctional Services Act 8 of 1959

Health Act 63 of 1977

Medicines and Related Substances Act 101 of 1965

National Building Regulations and Building Standards Act 103 of 1977

North West Municipal Structures Act 3 of 2000

Prevention of Illegal Conviction from and Unlawful Occupation of Land Act 19 of 1998

Private Security Industry Regulation Act 56 of 2001

Promotion of Administrative Justice Act 3 of 2000

Promotion of Equality and Prevention of Unfair Discrimination Act 4 of 2000

Promotion of National Unity and Reconciliation Act 34 of 1995

\section{Register of internet sources}

Donaldson 2012 www.politicsweb.co.za

Donaldson A 2012 Let's Never Mention Ubuntu Again www.politicsweb.co.za/politicsweb/view/politicsweb/en/page71619?oid=3111 $77 \&$ sn=Detail\&pid=71616 [date of use 16 Nov 2013] 


\section{List of abbreviations}

PELJ Potchefstroom Electronic Law Journal

SAJHR South African Journal of Human Rights

SAPL Southern African Public Law

Stell LR Stellenbosch Law Review 